
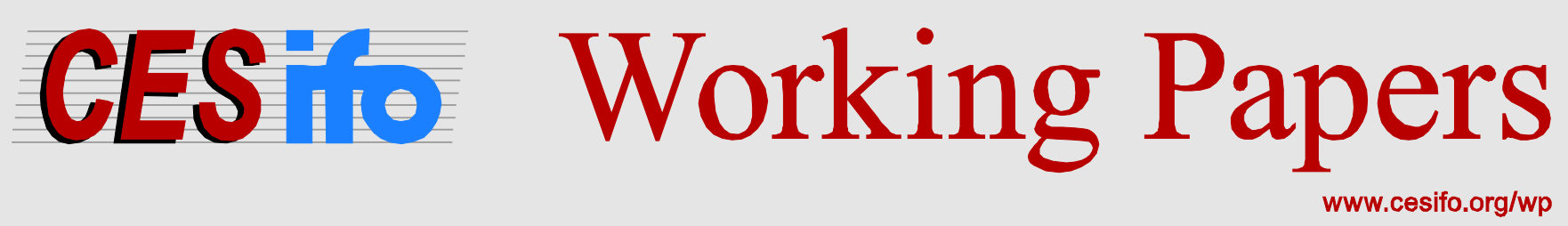

\title{
Railways and the Productivity Gap in Italy: Persistence and Divergence after Unification
}

\author{
Nicola Pontarollo \\ Roberto Ricciuti
}

\author{
CESIFO WORKING PAPER NO. 5438 \\ CATEgory 6: Fiscal POLICY, MACROECONOMICS AND GROWTH \\ JULY 2015
}

An electronic version of the paper may be downloaded

- from the SSRN website:

- from the RePEc website:

- from the CESifo website:

www.SSRN.com

www.RePEc.org

www.CESifo-group.org/wp 


\title{
Railways and the Productivity Gap in Italy: Persistence and Divergence after Unification
}

\begin{abstract}
The political unification of Italy in 1861 led to the establishment of a single market, by removing the trade barriers across the pre-existing states, with a single currency. Market integration was the economic outcome of this process. At the same time, the Kingdom of Italy started a large infrastructure project to spread railways, which were largely confined in Northern Italy, all over the country. Using tools from spatial econometrics, we find that railways played a positive effect on productivity, but this effect was stronger in the areas in which railways were already built. Moreover, railways helped industrial firms to locate closer to water sources and gain access from there to the overall market. This effect is in line with New Economic Geography according to which infrastructure lead to a widening of territorial disparities.
\end{abstract}

JEL-Code: N730, N930, L920, C230, O180.

Keywords: railways, productivity, economic growth, spatial econometrics.

Nicola Pontarollo

Department of Economics

University of Verona

Vicolo Campofiore 2

Italy - 37129 Verona

npontarollo@gmail.com
Roberto Ricciuti*

Department of Economics

University of Verona

Vicolo Campofiore 2

Italy-37129 Verona

roberto.ricciuti@univr.it

*corresponding author

We thank seminar participants at the University of Munich for useful comments. 


\section{Introduction}

The political unification of Italy in 1861 led to the establishment of a single market, by removing the trade barriers across the pre-existing states, with a single currency. Market integration was a corollary of this process, and more productive Northern industries had the opportunity to reach a larger market, further reducing their average costs and boosting their productivity. Low-productivity Southern firms were crowded-out. At the same time, the Kingdom of Italy decided to start a large infrastructure project based on railways. Railways were largely confined in Northern Italy and the political elite choose this project in order unite Italy, giving also a vision to the new established state.

In this paper we analyze the interplay between market forces that lead to concentration and this policy effort. In principle railways may reinforce the concentration process since they reduce transportation costs, ${ }^{1}$ making Northern goods cheaper further displacing Southern ones. However, the transportation cost argument may also apply to Southern firm, which could at least partially offset their productivity-disadvantage.

Public capital, in general, and infrastructure, in particular, have been regarded as “"unpaid factor(s) of production' which directly encourage increased output; 'augmenting factors' which enhance the general productivity of private capital and labor inputs; and in a more dynamic sense incentives for firm and household (re)location and long term economic growth" (Lewis 1998, p. 142).

Our main finding is that railways play a crucial role with respect to productivity. This effect is in line with New Economic Geography according to which infrastructure lead to a widening (rather than to a reduction) of territorial disparities: by providing central and peripheral regions with a similar degree of accessibility, lagging provinces result to be disadvantaged, as their firms are in a weaker position to compete than firms in the core (Puga, 2002). This is much more evident in post-Unification Italy where the fundamental immovable production factors were the natural resources. We extensively use spatial econometrics techniques to assess the importance of relative location in space. These techniques allow us to analyze, both statistically and visually, the main spatio-temporal dynamics of the selected variables. We first use an exploratory spatial data analysis (ESDA) that allows us to disentangle spatial evolution of productivity and railways evolution. Then we examine the relationship between transport infrastructure and productivity with a spatial panel spatial filtering approach. This represents an advance with respect to classical technique because it is

\footnotetext{
1 The reduction of transportation costs and time can be an advantage because it eases the relocation of labor force and capital, and "reduces" the distance between the production site and the destination market.
} 
able to deal with spatially autocorrelated variables and it also accounts for omitted timeinvariant variables explicitly considering their spatial dimension.

The paper is organized as follows: Section 2 reviews the history of railways in Italy, while Section 3 discusses some issues related with the North-South divide. In Section 4 we exploit the geographical dimension of our data in order to identify some patterns. Section 5 introduces the modeling techniques, whose results are discussed in Section 6. Section 7 provide some robustness checks. Section 8 concludes.

\section{The history of railways in Italy}

Schram (1997) distinguishes four phases in the development of railways in Italy. The first one took place from 1839 (when the first line was built) to 1865, foreign private companies built the main lines under concession from the pre-unitary states (figure 1). Piedmont was an exception, since the railways was built and managed by the state from 1950s. The concessionary regime was different across states and also within the same state, leading to confusion and disparities across the companies. After Unification in 1961, a spur of investments took place (figure 2), with foreign investors willing to increase their involvement, given the plans of the new state, and its higher merit of credit. It should be noted that more than half of the state's spending in the 1860s and 1870s was on railways. Recently Dincecco et al. (2011) suggested that Piedmont's investment in railway in the 1850s was also motivated by the necessity to gain support from the merchant elites for the military expenditures needed in the unification campaign.

The second phase started in 1965 with the Railways Act that reorganized railways companies among five franchisees (Upper Italy Railway Company that run the service in the North, the Meridionali Railway Company, which managed the line between Tuscany and the Adriatic South, the Romanae Railway Company in central Italy, Reale Sarda Railway Company in Sardinia and the Victor Emmanuel Railway Company in Sicily). Moreover, the Piedmontese State Railways were privatize because of the financial needs of the Kingdom, and the Upper Italy Railway Company was formed. The aim of the Act was to attract capital in order to expand the rail network by offering a high rate of return.

However, the returns were often negative and companies were bailed out by the state. In fact by 1878 - which marks the beginning of the third phase - the government was in charge of most of the tracks and operating companies. In 1885 a second Railway Act passed, opting for a mixed system in which the tracks were state-owned, whereas the three operating companies (the Mediterranean Railway Company that operated the western network, the 
Adriatic Railway Company that was in charge of the eastern network, and the Sicilian Railway Company that ran the railways in the South and in the main islands) were left to the private sector. The act pushed the construction of secondary railways as a complement of the main lines. The last phase began with the nationalization in 1905 that was needed because of the poor performance of Mediterranean and the Adriatic railway companies. This phase saw an increase in investments ran by the state-owned Ferrovie dello Stato. ${ }^{2}$

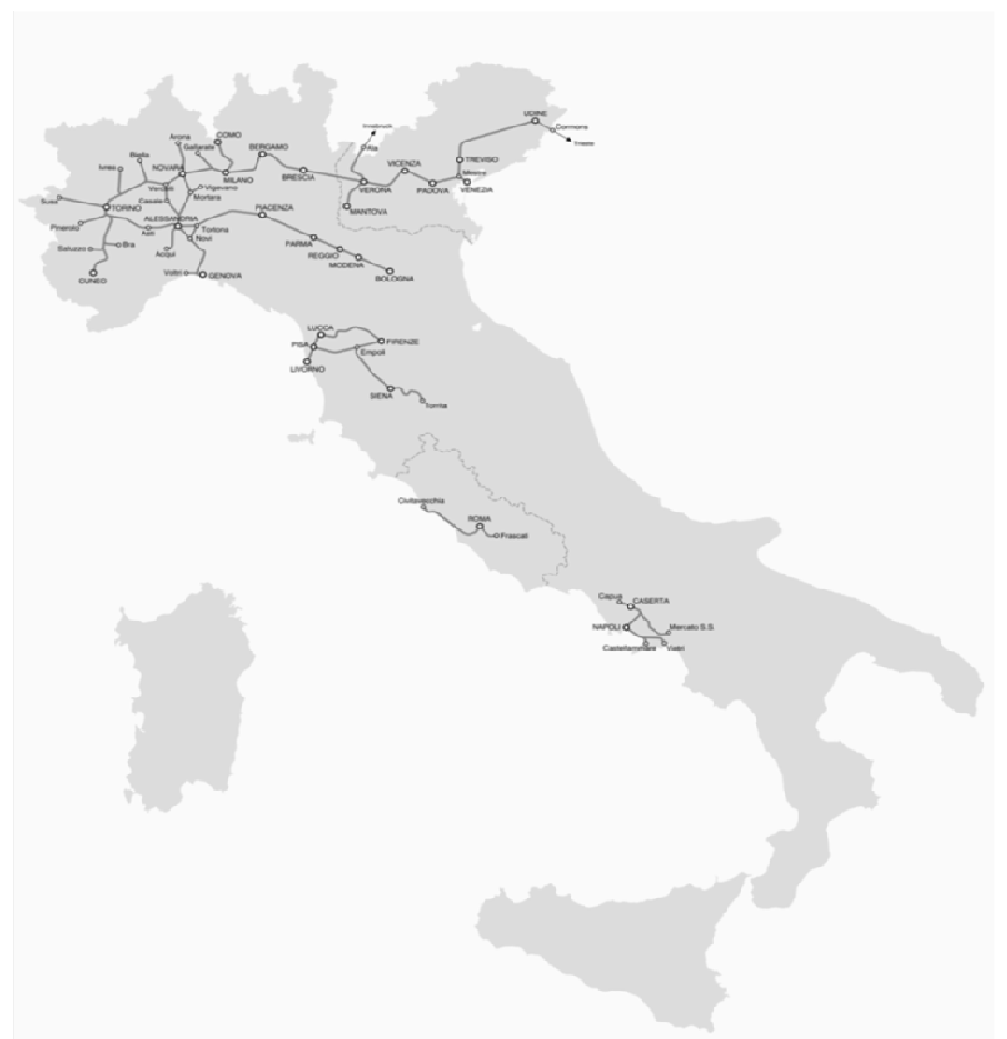

Figure 1 - Railways in 1861

\footnotetext{
${ }^{2}$ To some extent this phase ended at the late 1990s, when some EU-promoted liberalizations started, mainly in the cargo sector, and a duopoly on passengers high-speed lines was established with a private-owned company in 2010 .
} 


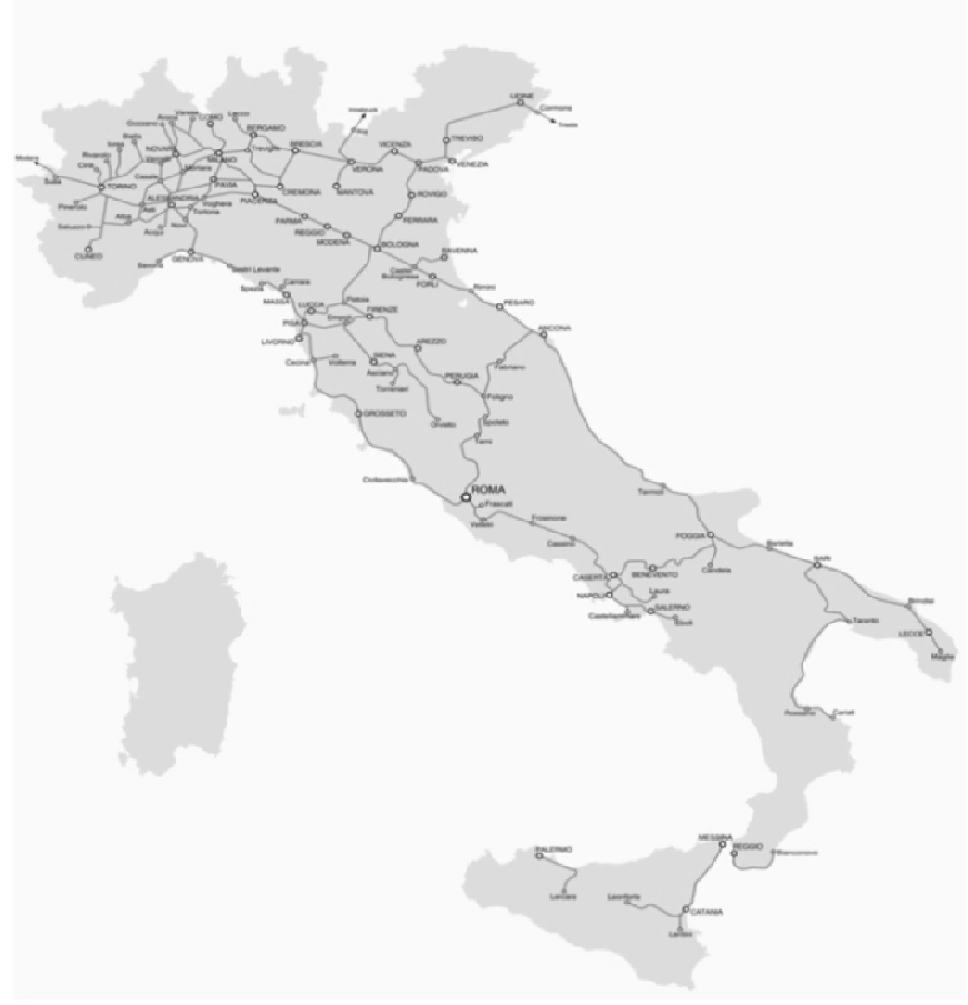

Figure 2 - Railways in 1870

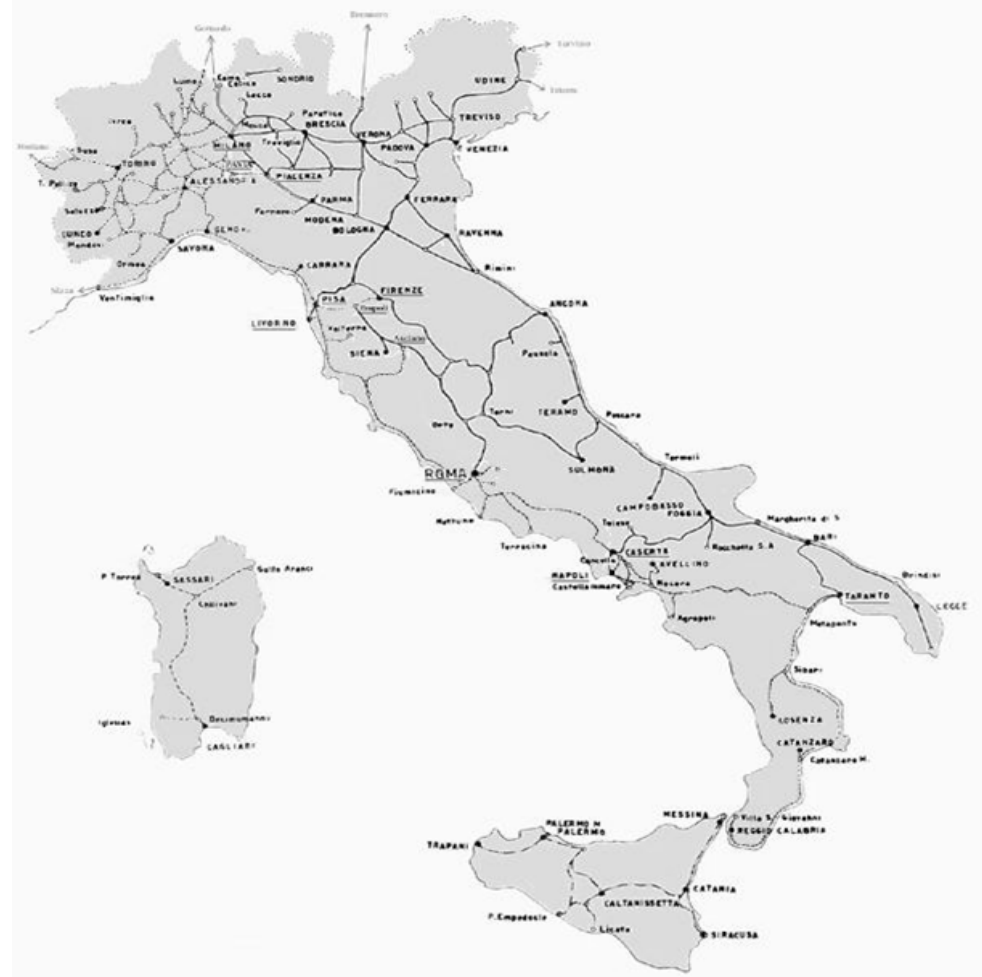

Figure 3 - Railways in 1885 
The early literature on railways was concerned with the consequences of this infrastructure on growth.

Romeo (1959) interpreted the resources devoted by the state to the construction of railways (and other public services) as a mechanism that, through taxation and government spending, redirected wealth from the relatively rich agriculture to the infant manufacturing sector. Investing in railways was a form of capital accumulation, conducive to the take-off of the Italian economy in the following decades. The Marxist interpretation was given by Sereni (1966) who claimed that railways fulfilled the aim of the bourgeoisie to create a unified market, and its cost was borne by the working class. Both the liberal and the left-wing approaches placed a lot of emphasis on the role of infrastructure, but they differed on the evaluation burden of this investment.

Gerschenkron (1962) was the first scholar to call into doubts the positive effects of railways on economic growth. He maintained that the railway network was built too early with respect to the industrialization of the country. During the first wave of investments in the 1880s, it needed imports from abroad since there was not enough domestic supply of investment goods, therefore there was no supply to meet this demand. At the time of the second wave of investments after nationalization, it was too late to contribute to industrialization. Railways failed to unify the market because there was not enough national demand, and their cost was too high with respect to the benefits. Had the timing of investments in railways been different, the growth rate in the Giolittian age would have been higher.

Fenoaltea $(1983,2011)$ downplayed the role of backwardness of the Italian manufactures because most of the work at the time of the building the railway network was labor-intensive, whereas it became capital-intensive when carriage was substituted and improvement works took place. At that time domestic manufacturers were technologically updated, and procurement directed to national producers also helped them. Nonetheless, Fenoaltea shares the idea that railways did not bring a unified market, but for completely different reasons. First, lines were subsidized by the state according to their actual length and not the air-distance between two cities, incentivizing long and tortuous railways that in the end were ineffective in cutting down journey times. Second, the fare structure was too costly for long-distance journeys. As a results of these causes, the railway network was used much below capacity, which in turn led to negative returns, underinvestment by the private companies and in the end nationalization. State-ownership was also inefficient because it expanded the personnel in absence of a similar increase in traffic. 
More recent studies were microeconomic in nature. Bogart (2010) applied a stochastic frontier methodology to estimate the inefficiency of state ownership in railways in 18 countries in 1880-1912, the time of increasing nationalization of the sector. In the 1890s Italy (together with Sweden, Austria, and Switzerland), which turned to the least efficient in the 1900s. Inefficiency increased costs by $2.7 \%$ (against the average 5.4\%) in 1890-1899 and $7.3 \%$ (with respect to the average 5.8\%) in 1900-1912. In a counterfactual estimation, the author finds that no nationalization and no more than $25 \%$ state ownership would have brought about a $1.7 \%$ increase in efficiency.

Ciccarelli and Nuvolari (2015) cast doubt on the current and prevailing view in the literature, that upward linkages between railway construction and the mechanic industry were extremely limited because of the technical backwardness of the Italian steam locomotive sector (Schram, 1998). ${ }^{3}$ Notwithstanding the limited endowment in terms of engineering skills and competences, the Italian steam locomotive industry showed a good performance in basically the same period we consider in this paper. Italian locomotives were of a level of technological sophistication similar to that of foreign exemplars. This process of development was disturbed by the vagaries of the demand which prevented the major national players from planning an ordered expansion of productive capacity and by the tariff protecting iron products. However, from 1885 onwards national manufacturers received a considerable help through a discretionary procurement policy. This industry was concentrated in the industrial triangle (Turin-Milan-Genoa) and in Campania (Ciccarelli and Fenoaltea, 2012).

\section{The North-South divide}

There is an established literature on the economic dualism between the North and the South in Italy that spans the last sixty years, starting with Romeo (1959) and Gerschenkron (1962). Only recently regional estimates of industrial production and GDP have been produced. Felice (2011) has constructed regional disaggregations of the new national-product estimates for 1891, 1911, 1938, 1951, 1971 and 2001; Daniele and Malanima (2007) interpolated

\footnotetext{
${ }^{3}$ An early contribution claiming pointing out the weaknesses of the Italian mechanical industry is put forward by Merger (1986). The limited number of locomotives produced in the period 1861-1885 is due to three factors: the limited depth of the technological capabilities of the national firms, the lack of specialization, and the penalties induced by the tariff. After the 1885 Act, a new wave of investment took place that benefited national producers through public policy. The ultimate consolidation of the national industry of steam locomotives, according to Merger, takes place after 1905 when the production of national producers is elicited by the wave of investment following the creation of state company.
} 
similar benchmarks to generate annual regional income series from 1891 to 2004. Starting from Fenoaltea (2003), a large number of regional series have been produced by the same author disaggregating across industries and services using census labor-force data for the years $1871,1881,1901$, and 1911.

Ciccarelli and Fenoaltea (2013) take a step forward and provide measures of industrial production for the 69 Italian provinces for the same years. The picture they provide is faceted. In the aftermath of Unification the leaders were in former capital cities, where there was a strong base of artisans, and a small part of the South, where selected provinces reaped the gains from the freer foreign trade (the extension to the whole country of the free-trade policy of the piedmontese Kingdom), and infrastructure investment. But this was a short-term effect: over the later nineteenth century, when the movement from craftsmanship to industry became stronger, industry concentrated into the 'industrial triangle'. The early twentieth century, brought both industrial diffusion and concentration. The latter to the center/northeast, where it was tied to the production of perishables on recently improved land, the latter within the north-western triangle itself, into its major cities. This movement was brought by progress in energy transmission, which made production of goods less tied to the waterfalls from which electricity was produced.

Figure 4 depicts the quintiles of the Gross Value Added/male population in the first and the last years considered in our analysis. Male population is a proxy for labor force.

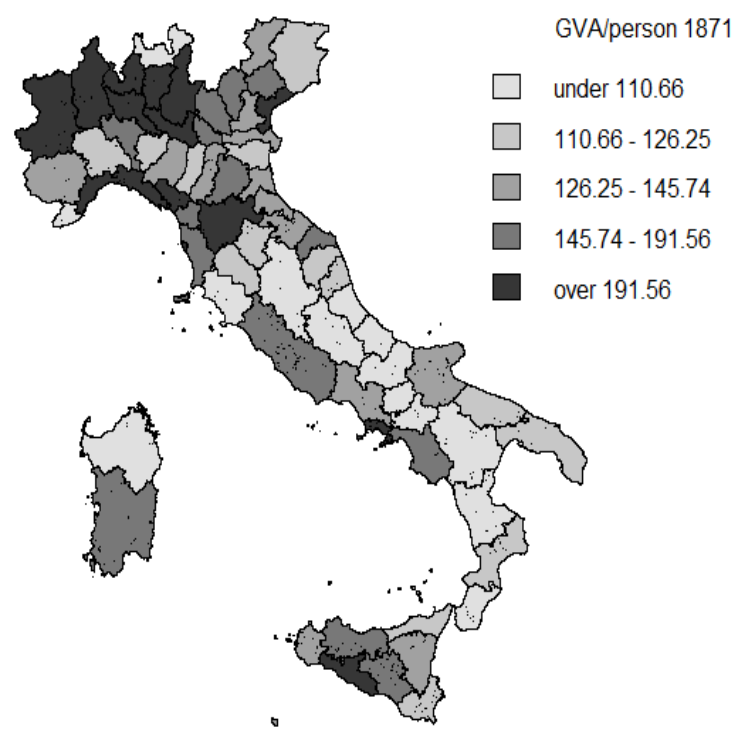

a) 1871

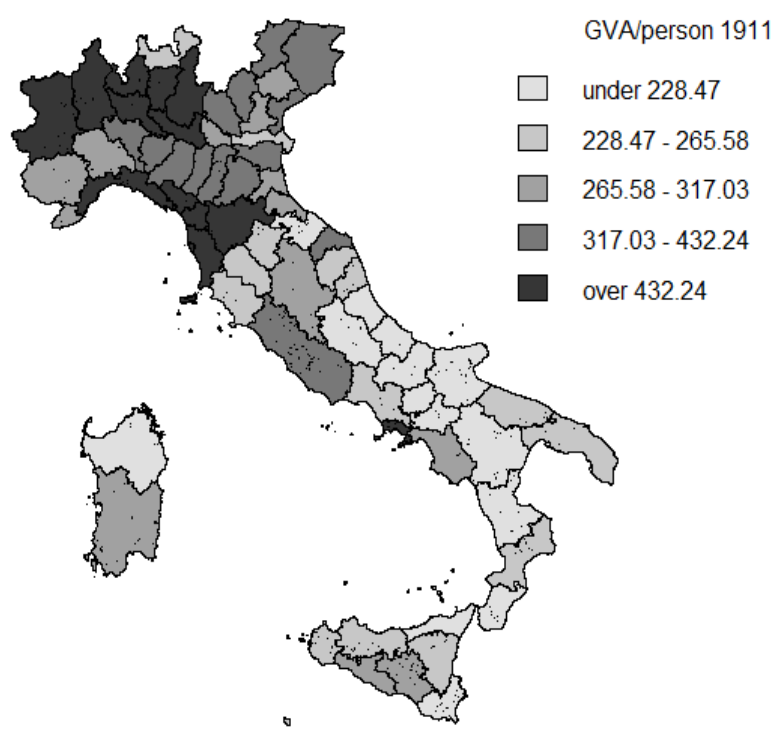

b) 1911

Figure 4 - Gross value added/male population in 1871 and 1911 
We can see the two movements mentioned above: concentration and limited diffusion. Provinces in the first quintile in 1871 remain there (with the exception of Venice), and are joined by a few contiguous provinces. At the same time, provinces in the North/North-East tend to become darker, therefore upgrading in the distribution. However, provinces in the South go down in the development ladder in relative terms, as shown by their lighter colors.

According to Ciccarelli and Fenoaltea, railways play some role in this pattern. For example, in the North-West there are two opposite cases. Cuneo, in south-west Piedmont, exploited his position on the road from Turin to Nice until the latter was ceded to France because of the Turin Treaty in 1860. Then the rail line was built from Genoa to Turin through Alessandria, sidelining Cuneo. Genoa was one of the main beneficiaries of railway construction: the inland railway was used to ship the goods produced in the upper Po valley through its port, avoiding transportation along the lower Po valley to the Adriatic Sea. Also these provinces were cut from trade done by river navigation, that up to the introduction of railways was the cheapest transportation mean.

Besides these local effect, Ciccarelli and Fenoaltea (2013: 72) claim that "The postUnification peninsular railways do not appear to have unified the domestic market, let alone done so to the detriment of the south; the pre-Unification northern railways appear to have reoriented trade, to the detriment of the lower Po valley."

\section{Data and their geographical structure}

The data used in this empirical analysis refer to 69 provinces and 4 benchmark years (1871, 1881, 1901 and 1911). ${ }^{4}$. The data on Gross Value Added, male population over 15 and area are from Ciccarelli and Fenoaltea (2013), $\mathrm{km}$ of railways are from Ministero delle Comunicazioni, Ferrovie dello Stato (1927) and $\mathrm{km}$ of roads ${ }^{5}$ and population from L'Italia Economica (1873) and Annuario Statistico Italiano (1892, 1900 and 1912).

Figure 5 depicts the quintile maps of the mentioned variables for each year. Railways appear rather concentrated in the north-western and in the center-north of Italy in 1871, while, in 1911, they seem a little more sparse. Anyway, a clear spatial pattern is not evident neither in the first or in the last considered year. Some areas that in 1871 were characterized by a low density of this infrastructure kept their advantage, while others caught up from the

\footnotetext{
${ }^{4}$ In 1891 there was no census.

${ }^{5}$ Due to availability problems, we have data for roads on $1872,1880,1897$ and 1910 which are used for the most proximate benchmark year.
} 
initial lagging situation. The railways were considered a driver of political unification (Cavour, 1976) and economic development (Ferrovie dell'Alta Italia, 1865). ${ }^{6}$

This was particularly urgent for the Center-South of the peninsula, in which the situation was particularly precarious. In the context, and in a period characterized by the emergence of the steam engine and train as main transport modality, the road was conceived to get to the nearest railway station, extending the social and economic effects beyond the few centers touched from the platform (Bandon, 2011). The law on public works (attached to the law March 20, 1865, n. 2248, for "the administrative unification of the Kingdom") classified the roads in four categories: national, provincial, municipal and vicinal.

According to the law (art. 10), national roads were: a) the broad roads that directly join several of the leading cities of the kingdom, or those with the closest commercial ports of the first class (Trieste, Venice, Livorno, Naples, Messina, Palermo); b) those roads that connect the previous roads to large commercial lines of neighboring countries; c) the major roads crossing major brands of the Alps and Apennines; d) those roads that have a purpose exclusively military. Given the importance of the rail, art. 11 stated that there could not be a national road between two points of the territory linked by a railway, which meant to downgrade several national roads to provincial as rail network was developed.

Provincial roads (art. 13) were: a) the roads that serve the more direct communication between the capital of a province and those of neighboring provinces; b) those roads that connect the capital of a province to the capitals of the districts in which it is divided; c) those roads that connect the provincial capitals with the most important neighbors seaports; d) those roads that are recognized of great importance for industrial, commercial and agricultural relations.

Finally, with the law on so-called "mandatory municipal roads" (August 30, 1868, n. 4613) the municipalities were forced to build and fix roads in the following cases: a) to link the center of the town to the capital of the same district or to the main center of the nearest town; b) to get in communication with railways and ports or other existing roads; c) to connect to each fraction with the others.

In figure 5 we observe that in both periods mandatory municipal roads were mainly concentrated in the northern part of the peninsula. The provincial and national roads change

\footnotetext{
${ }^{6}$ Giornale del Genio civile, official part (1869, p. 316), for example, reported that in several provinces of the kingdom the need of carriage roads is perhaps above anything else. These provinces will never reach prosperity until there will not be a communications network which serves to fertilize every kind of industry and business transactions.
} 
their spatial patterns between the first and the second considered year. In 1871 they were much more concentrated in the center-north part of Italy, while in the last year the northern part was characterized by a lower concentration, probably because the development of the railway was so strong and widespread to make not necessary the construction of such type of roads.
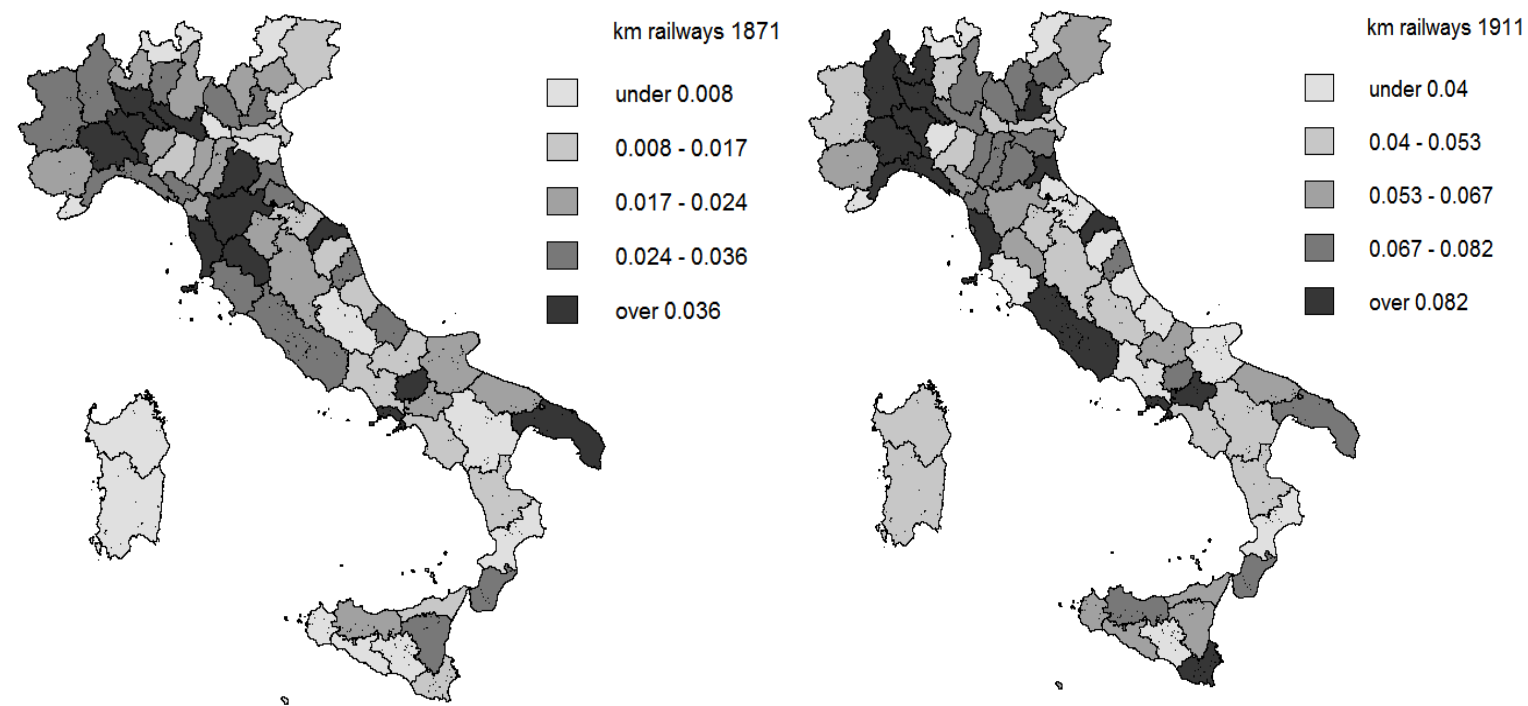

a) $\mathrm{km}$ railways/area 1871

b) $\mathrm{km}$ railways/area 1911
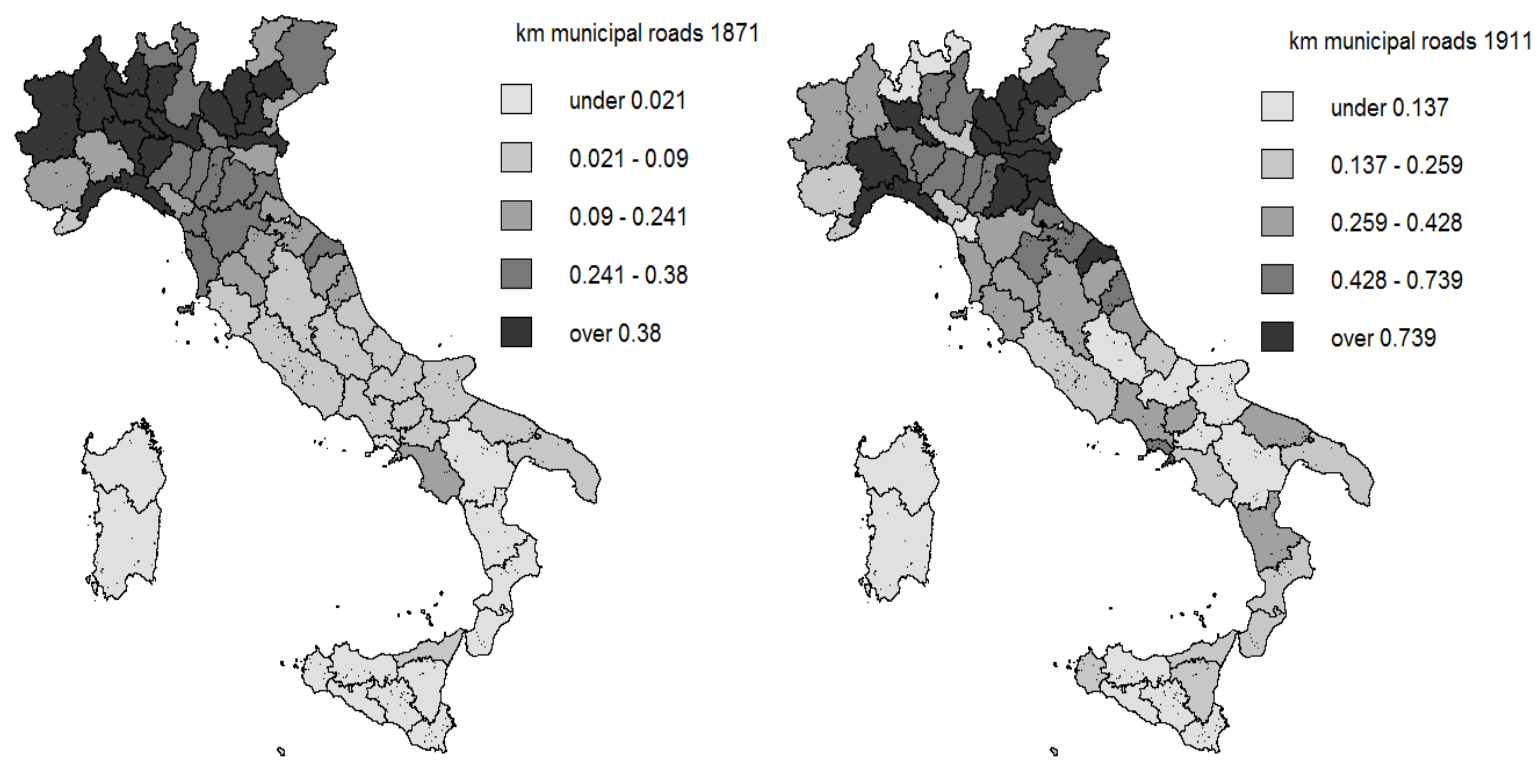

c) $\mathrm{km}$ communal roads/area 1871

d) $\mathrm{km}$ communal roads/area 1911 


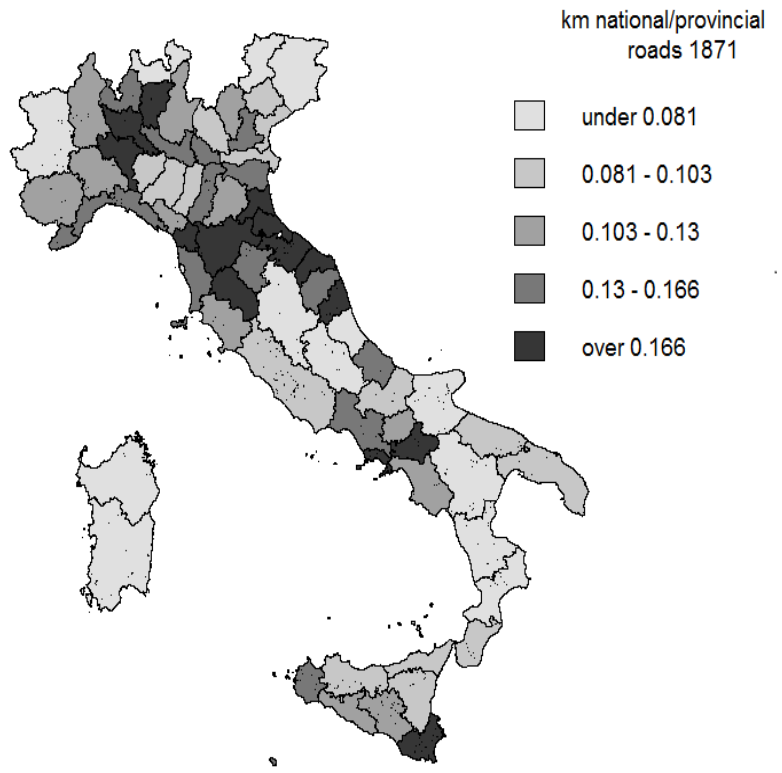

e) $\mathrm{km}$ provincial and national roads/area 1871 1911

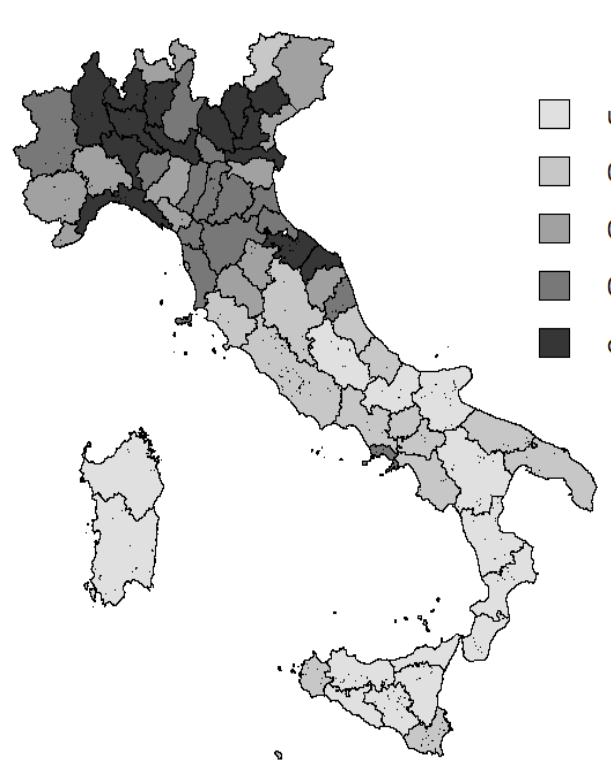

g) $\mathrm{km}$ total roads/area 1871

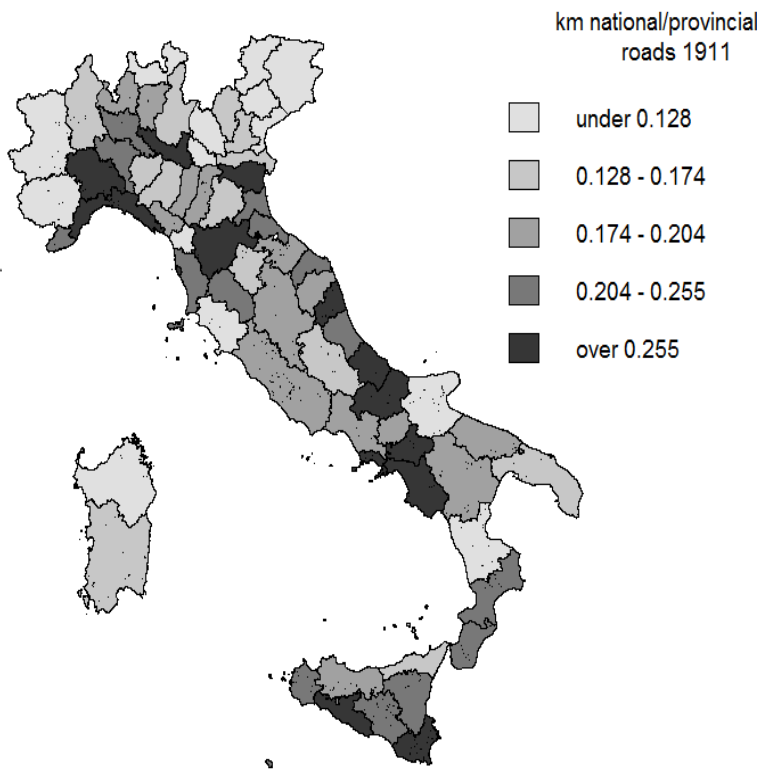

f) $\mathrm{km}$ provincial and national roads/area

Figure 5 - Quintile map of infrastructural level in 1871 and 1911

Despite such strong infrastructure development, Mazzoleni (1875) observed that the progressive increase of returns from the railways in a young state like Italy, which should develop its trade and industries, was instead arrested, and for some time marked a decrease which denotes the slow activity of industrial trade and in general of business. According with 
the author, the excessive tax burden paralyzes private and industrial initiatives and trade. Credit decreased and capital, from industry and trade, turned government assets, which were safer and more lucrative. According to Fenoaltea (2007), in 1871 the artisanship is concentrated where there are the customers, i.e. the courts, while industry and manufacturing in the regions that have inherited the legacy of old capital. In the post-unification period the location of the factories follows a different logic: the direct contact with consumers loses importance because the factories produce for a broader market rather than a strictly local area. In this context, environmental resources that minimize production costs and attract mobile factors become crucial. The author maintains that the success of the North and the failure of the South are related to natural resources because in the first industrial revolution technology was intensive in natural resources - such as water - that were widely available in the North. The ease of transportation made it possible to attract capital and work from other locations, making decisive the forces of attraction of the fixed natural resource. This is confirmed by figure 4 a) and b), where we visually observe that the Gross Value Added per male person over 15, used as a proxy of labor force (Ciccarelli and Fenoaltea, 2013), is much more concentrated in the North in 1911 than in 1871.

The spatial dimension of the selected variables, clearly shown in figures 4 and 5, can be investigated through the Moran's I $(M I)$, which provides a single summary statistics describing the degree of clustering in spatial data. It is defined as:

$$
M I=\frac{n}{\sum_{i=1}^{n} \sum_{j=1}^{n} w_{i, j}} \frac{\sum_{i=1}^{n} \sum_{j=1}^{n} w_{i, j}\left(y_{i}-\bar{y}_{i}\right)\left(y_{j}-\bar{y}_{j}\right)}{\sum_{i=1}^{n}\left(y_{i}-\bar{y}\right)^{2}}
$$

where $i$ and $j$ refer to different spatial units (i.e., cell centroids) of which there are $n, y$ is the data value in each and $w$ the element of the line $i$ and row $j$ of the spatial weights matrix $\mathbf{W}$ of $n \times n$ size. The calculated Moran's I for global autocorrelation varies between -1 and 1 . A positive coefficient corresponds to a value of Moran's I that is larger than its theoretical mean of $-1 / \mathrm{N}-1$, or, equivalently, a positive $\mathrm{z}$-value, and points to positive spatial autocorrelation, i.e. similar values cluster together in a map. The reverse represents regimes of negative association, i.e. dissimilar values cluster together in a map.

The choice of spatial weights matrix $\mathbf{W}$ is based on potential accessibility (ESPON, 2007), based on the assumption that the attraction of a destination increases with size, and declines with distance, travel time or cost. Potential accessibility is a construct of two functions, the activity function representing the activities or opportunities to be reached and 
the impedance function representing the effort, time, distance or cost needed to reach them (Wegener et al., 2002). For potential accessibility the two functions are combined multiplicatively, i.e. are weighted to each other and both are necessary elements of accessibility:

$$
w_{i j}=A_{j} \exp \left(-\beta d_{i j}\right)
$$

where $w_{i j}$ is the accessibility of province $i, A_{j}$ is the activity $A$ to be reached in province $j$, and $d_{i j}$ is the distance of reaching province $j$ from province $i . w_{i j}$ is the total of the activities reachable at $j$ weighted by the ease of getting from $i$ to $j$. The interpretation is that more province $j$ is attractive, and the more is accessible from province $i$, the greater is the accessibility of province $j$ with respect to $i$. Or, in other terms, province $j$ is much more close to province $i$ in term of market potential.

The accessibility model calculates the minimum distance between each pair of provincial capitals. For each province the total value of the potential accessibility indicator is calculated by summing up the $A_{j}$ in all other provinces, weighted by the distance to go there. For this weighting, the parameter $\beta$ has been set to 0.02 , as customary when we consider national trips (Andersson and Karlsson, 2007).

In our spatial weights matrix, following (ESPON, 2007), $A_{j}$ corresponds to provincial population. We also imposed that each province must have at least one neighbor and set a cut-off distance of $110 \mathrm{~km}$ to avoid to include neighbors with negligible weights. The idea behind this choice, largely accepted in spatial econometrics, is to construct a spatial weights matrix that accounts for the important linkages among regions, avoiding to include too much neighbors. A typically used $\mathbf{W}$, for example, in constructed on the basis of a queen contiguity matrix, which consider as neighbor the regions that touch themselves with at least a point of the borders. In a robustness check we will use the mentioned matrix. The spatial weights matrix is then standardized by row. This is useful for the computation of the $M I$ because in this way we will be able to relate each variable with the values of the variables of the neighbor provinces weighted by the number of these neighbor provinces.

In table 1 we report the descriptive statistics and the Moran's I of the selected variables that we will use in our econometric model by year. The Gross Value Added per working age male person is strongly spatially autocorrelated and it tends to be much more clustered over the time. This clearly shows an increasing polarization of the industry, a result found also by Ciccarelli and Fenoaltea (2013) using a different methodology and observed also in the increasing gap between the more and less productive provinces. The railways are 
rather positively autocorrelated only until 1871 , with a p-value of 0.035 , and in the following periods they are much more randomly distributed in space, highlighting the role of the central Government in bridging the gap among provinces with respect to this particular kind of infrastructure. The average $\mathrm{km}$ of railways over square kilometers triplicates between 1871 and 1911, but there are still provinces without rail accessibility. Also population density is not clustered and does not follow a defined spatial pattern. There are permanent differences between provinces with zones of sparse population and others with strong polarization that tend to attract people from other areas.

Finally, the municipal roads density, as observed in figure 5, is characterized by a strong spatial pattern, confirmed by the Moran's I for all examined years. However, the construction of new infrastructure tends to mitigate this situation. Municipal roads in 1871 were strongly clustered in the North of the peninsula (Moran's I $=0.80$, p-value $<0.001$ ) but the situation improved over time with a spatial autocorrelation index equal to 0.36 (p-value < 0.001) in 1911 pointing to a more homogeneous distribution. The density of municipal roads is stronger than national/provincial roads over the whole period, but it is noteworthy that there are provinces where there are no municipal roads, which means that there are municipalities without adequate connections with capital cities or with the main communication network. National and provincial roads are more equally distributed across provinces as shown by the not significant Moran's I. The exception is year 1901 and it is due to three outliers (Avellino, Chieti and Naples).

Table 1: descriptive statistics

\begin{tabular}{llllll}
\hline Variables & Mean & Std. dev. & Min. & Max. & Moran's I \\
\hline GVA/male pop. 1871 & 147.700 & 46.094 & 76.470 & 266.40 & $0.345(<0.001)$ \\
GVA/male pop. 1881 & 167.800 & 56.021 & 86.360 & 322.400 & $0.313(<0.001)$ \\
GVA/male pop. 1901 & 232.200 & 98.745 & 111.400 & 576.500 & $0.459(<0.001)$ \\
GVA/male pop. 1911 & 334.700 & 150.664 & 174.300 & 858.900 & $0.556(<0.001)$ \\
Railways 1839-1871 & 0.021 & 0.023 & 0.000 & 0.132 & $0.140(0.035)$ \\
Railways 1839-1881 & 0.035 & 0.025 & 0.000 & 0.132 & $0.040(0.265)$ \\
Railways 1839-1901 & 0.059 & 0.036 & 0.000 & 0.269 & $0.043(0.230)$ \\
Railways 1839-1911 & 0.066 & 0.040 & 0.000 & 0.307 & $0.072(0.129)$ \\
Agglomeration 1871 & 122.500 & 124.960 & 22.800 & 999.700 & $0.030(0.234)$ \\
Agglomeration 1881 & 130.100 & 136.935 & 24.380 & 1103.000 & $0.023(0.267)$ \\
Agglomeration 1901 & 147.300 & 157.410 & 28.860 & 1269.000 & $0.000(0.400)$ \\
Agglomeration 1911 & 159.000 & 180.141 & 31.110 & 1444.000 & $-0.017(0.515)$ \\
Municipal roads 1871 & 0.230 & 0.227 & 0.000 & 0.947 & $0.803(<0.001)$ \\
National/provincial roads 1881 & 0.203 & 0.202 & 0.002 & 0.955 & $0.569(<0.001)$ \\
National/provincial roads 1901 & 0.230 & 0.165 & 0.000 & 0.908 & $0.562(<0.001)$ \\
National/provincial roads 1911 & 0.327 & 0.337 & 0.006 & 1.481 & $0.356(<0.001)$ \\
National/provincial roads 1871 & 0.127 & 0.067 & 0.043 & 0.455 & $0.070(0.154)$ \\
Distance from ports 1881 & 0.137 & 0.054 & 0.048 & 0.407 & $0.132(0.041)$ \\
National/provincial roads 1901 & 0.172 & 0.055 & 0.068 & 0.426 & $0.338(<0.001)$ \\
National/provincial roads 1911 & 0.224 & 0.210 & 0.047 & 1.690 & $0.019(0.297)$ \\
\hline
\end{tabular}

In parenthesis the $\mathrm{p}$-value 
The spatial relation described by the Moran's I can be shown in the Moran scatterplots which relate a selected variable with its spatially lagged values. Thus, each of the points in the scatterplot represents a combination of a provinces' value and its corresponding spatial lag. The values on the $\mathrm{x}$ - and $\mathrm{y}$-axes are standardized so that the vertical and horizontal lines represent the average values and divide the scatterplot into 4 quadrants (anticlockwise from top right): in the first and third (high-high, HH, and low-low, LL, respectively) a province that exhibits a high (low) value of the variable is surrounded by provinces with a high (low) value of the variable as well. In the second and fourth (low-high: LH and high-low: HL, respectively) a province with a low (high) value of the variable is surrounded by provinces with a low (high) value of the variable.

Intuitively, a concentration of values in quadrants $\mathrm{HH}$ and LL represents a clusterization of similar values, respectively low and high, in space, and then a positive spatial autocorrelation, in which provinces are surrounded by other provinces with similar values. This is related to the advantages of agglomeration economies. Conversely, there is negative spatial association when provinces are surrounded by others with different values (quadrants LH and HL).

Figure 6 shows the Moran scatterplot for GVA over male population. Most provinces are either in the first (top right) or third quadrant (bottom left). The number of provinces in each quadrant does substantially vary over time. The number of provinces in the first quadrant $(\mathrm{HH})$ shifts from $27.5 \%$ in 1871 to $18.9 \%$ in 1911 . The number of provinces in third quadrant (LL) strongly increases from 28 to 35 (from 40.6\% to 50.7\%), and in the second quadrant (LH) decreases from $20.3 \%$ to $18.9 \%$. Finally, in the third the number of provinces remained stable to $11.6 \%$.

The variations registered between the first and last years, as well as the higher $M I$ of year 1911 and the increasing concentration of points in third quadrant of Moran's scatterplot confirm the divergence between North and South of Italy. According to Rey et al. (2010: 5) "this comparative static view of the Moran Scatter Plot provides an overall impression of the spatial dynamics yet it may mask, or even misidentify, individual movements of economies and their neighbors".

Thus to avoid such a risk, following Rey (2001) the dynamics of transition between the four different types of spatial association outlined above (HH, LH, LL, HL) is reported in table 2. The main diagonal shows the percentage of provinces that do not move from their 
original quadrant. The higher persistence has been in the first and third quadrants with around $63 \%$ and $96 \%$ of provinces, respectively, that did not change their original cluster.


Figure 6: Moran's I scatterplot for GVA/male population in 1871 and 1911

Regarding the provinces in the second and fourth quadrants, they are residual and generally show a transition to a cluster of low productive provinces. The shift has been important if we consider that in 1871 there were 28 provinces in third quadrant (low-low) and in 1911 there were 35 . Table 2 allows us also to deepen the analysis with respect to the type 
of transition (Rey et al., 2010), i.e. if the transition involves a relative move of only the province or of its neighbors. The most important variation concerns the first and second quadrants, the first and second row, respectively. Regarding the first quadrant in 3 cases the provinces lowered their GVA over male population with respect to their neighbors and in other 3 cases both the province and the neighbors lowered their GVA over male population. In the second quadrant in 3 cases the neighbors decreased their levels of Gross Value Added/male population at the level of the considered province, while only one province increased its productivity per male person at the levels of the surrounding provinces.

Table 2: Moran Scatterplot transition probabilities for GVA/male population (1871-1911)

\begin{tabular}{|c|c|c|c|c|c|c|}
\hline & \multicolumn{4}{|c|}{1911} & \multirow{2}{*}{$\begin{array}{c}\text { Provinces by } \\
\text { quadrant in } 1871\end{array}$} \\
\hline & & High-high & Low-high & Low-low & High-low & \\
\hline \multirow{5}{*}{$\infty$} & High-high & $12(63.2)$ & $3(15.8)$ & $3(15.8)$ & $1(5.3)$ & $19(27.5)$ \\
\hline & Low-high & $0(0.0)$ & $10(71.4)$ & $3(21.4)$ & $1(7.1)$ & $14(20.3)$ \\
\hline & Low-low & $0(0.0)$ & $0(0.0)$ & $27(96.4)$ & $1(3.6)$ & $28(40.6)$ \\
\hline & High-low & $1(12.5)$ & $0(0.0)$ & $2(25.0)$ & $5(62.5)$ & $8(11.6)$ \\
\hline & Provinces by quadrant in 1911 & $13(18.9)$ & $13(18.9)$ & $35(50.7)$ & $8(11.6)$ & \\
\hline
\end{tabular}

In brackets percentage by row

\section{Model and estimation technique}

In this section we explicitly focus on the relation between infrastructure and provincial productivity, taking into account the time dimension of our data.

According to classical location theory, transport infrastructure endowment and investment lead to high returns. In this extent greater accessibility and lower transportation costs facilitate trade and lead to a reduction in the prize of traded goods, by allowing different territories to maximize their comparative advantage. The baseline model, similarly to HoltzEakin and Schwartz (1995), takes the form of an infrastructure-augmented, production function over time where we want to single out the correlation of disaggregated infrastructure stock and provincial productivity levels:

$$
Y_{t}=K_{t}^{\alpha} G_{t}^{\beta}\left(\psi_{t} L_{t}\right)^{1-\alpha-\beta}
$$

where $Y_{t}$ is the level of output, $K_{t}$ is the private capital, $G_{t}$ is the public capital, $L_{t}$ is the labor force and $\psi_{t}$ is an index of technical efficiency and $t$ the time periods. We consider that both $\psi_{t}$ and $L_{t}$ grow at constant rates. Taking the logs and dividing all variables by the effective quantity of labor we have the following equation:

$\ln y_{e t}=\alpha \ln k_{e t}+\beta \ln g_{e t}$ 
where the subscript $e$ denotes quantity per effective labor unit and $t$ time. In the model, public capital is represented by infrastructure and it is assumed to be complementary to labor and capital (Moreno and Lopez-Bazo, 2007). According to Barro (1990) when public infrastructure is an input in the production function, an increase in public infrastructure raises the marginal product of private capital, which leads to an increase in capital accumulation and then the speed the convergence. Another position comes from the New Economic Geography. Krugman (1991) and Krugman and Venables (1995) highlight that economic integration may lead to a "core-periphery" pattern due to the reduction in transportation costs. At this regard, the public investments in infrastructure have a crucial role in exacerbating or mitigating the spatial concentration of increasing returns to scale industries in the "core" and the concentration of constant returns to scale industries in the "periphery". Following Martin and Rogers (1995) and Martin (1998), public infrastructure facilitates transactions inside the region (intra-regional trade attracting firms and contributing to convergence). If the infrastructure is financed by the transfer facilitates inter-regional trade, rather than intraregional trade, then the regional policy can have a detrimental effect for the poor region.

In our empirical model we have quite detailed data on infrastructure, which refer to the $\mathrm{km}$ of railways, municipal mandatory roads and provincial/national roads, but we do not have data on capital. Then, in order to avoid model misspecification, we include some additional control variables and we adopt a technique able to deal with the problem of omitted variables and spatial dependence highlighted in the previous paragraph.

The empirical model is:

$$
\begin{aligned}
& \ln \left(G V A / M P O P_{i, t}\right)=\delta+\gamma_{1, t} \ln R A I L_{i, t}+\gamma_{2, t} \ln M U N_{-} R O A D S_{i, t}+\gamma_{3, t} \ln N A T_{-} R O A D S_{i, t}+\gamma_{4, t} \ln A G G_{i, t}+ \\
& \gamma_{5, t} \ln R A I L_{i, t} \times \ln M U N_{-} R O A D S_{i, t}+\gamma_{6, t} \ln R A I L_{i, t} \times \ln N A T_{-} R O A D S_{i, t}+\gamma_{7, t} \ln R A I L_{i, t} \times D_{\text {MORAN_RAIL }}+ \\
& \gamma_{8, t} D_{\text {MORAN_RAIL }}+\gamma_{9, t} D_{\text {SOUTH }}+\varepsilon_{i, t}
\end{aligned}
$$

where the subscript $i$ and $t$ denote, respectively, the province and the year and $\varepsilon$ the idiosyncratic error term. The variables are in logs and are the same described in the previous section. ${ }^{7} D_{M O R A N}$ RAIL represents a dummy that takes the value 1 for the provinces which lies in the first quadrant of the Moran Scatterplot with respect to their railways endowment until 1871 , i.e. the cluster of provinces that was the earliest adopter of this type of infrastructure. ${ }^{8}$

\footnotetext{
${ }^{7}$ The problem of some regions with zero kilometers of roads and/or railways has been overcome by adding a 1 to these variables.

${ }^{8}$ They include: Turin, Alessandria, Novara, Genoa, Pavia, Milan, Cremona, Bergamo, Leghorn, Pisa, Siena, Grosseto, Florence, Bologna, Ravenna, and Forlì.
} 
The dummy, then, meets two conditions: the first is that the railways were above the national average, and the second is that the railways were above the average also in the neighbor provinces. $D_{\text {SOUTH }}$ is a categorical variable that refers to the provinces of Southern Italy. ${ }^{9}$ Finally, we included two interaction terms to verify the relation between different types of infrastructure and the interaction terms between railways $D_{M O R A N_{-} R A I L}$ to test if the early railways endowment has an effect on improving the effectiveness of subsequent railways construction.

Our spatial model is based on the spatial contiguity matrix $\mathbf{W}$ and the associated Moran'I. If we rewrite equation (1) in matricial form we have:

$$
M I=\frac{n}{1^{t} \mathbf{W} 1} \frac{\mathbf{Y}^{t} \mathbf{M W M Y}}{\mathbf{Y}^{t} \mathbf{M Y}}
$$

where $\mathbf{M}=\left(\mathbf{I}-\mathbf{l l}^{t}\right) / n$ is the matrix in which $\mathbf{I}$ is the identity matrix of size $n$-by- $n, \mathbf{I}$ is a vector of one dimension $n$-by- 1 and the apex $t$ points the transposed matrix. The peculiarity of the $\mathbf{M}$ matrix is that it centers the vector of data value Y. Tiefelsdorf and Boots (1995) demonstrate that each of the $n$ eigenvalues of expression MWM is a value of the Moran's I, once it is multiplied by the left-hand term of expression (6), namely $n / \mathbf{l}^{t} \mathbf{W l}$. This allows the extraction from the $n$-by- $n$ matrix of uncorrelated numerical orthogonal components (Tiefelsdorf and Boots, 1995). This nonparametric approach has the aim of managing the presence of spatial autocorrelation by introducing a set of variables, the eigenvectors, able to catch the latent spatial association of georeferenced variables (Getis and Griffith, 2002). The first eigenvector, $E_{1}$, is the set of numerical values that has the largest value of $M I$ for the given spatial weights matrix. The second eigenvector, $E_{2}$, is the set of numerical values that has the greatest value of $M I$ for each set of numerical values not correlated with $E_{1}$. This sequential construction of eigenvectors continues until $E_{n}$, a set of numerical values that has the largest value of $M I$ achievable by any set of numerical values that is uncorrelated with the previous $n-1$ eigenvectors. These $n$ eigenvectors describe the full range of possible orthogonal, unrelated spatial patterns and can be interpreted as a summary map of variables that describe the nature (positive or negative) and the level (low, moderate, high) of spatial autocorrelation. Selected eigenvectors can be used also as predictors instead of not explicitly considered variables (Fischer and Griffith, 2008) and, since they are both orthogonal and uncorrelated, a stepwise linear regression can be used to achieve this end.

\footnotetext{
${ }^{9}$ Abruzzo, Molise, Campania, Puglia, Basilicata, Calabria, Sicilia and Sardinia commonly belong to this area.
} 
In case of spatial panel, as highlighted by Patuelli et al. (2011), the stages of the spatial filtering approach are:

1) Calculate the eigenvectors of the spatial weights transformed in MWM.

2) Select from the MWM matrix the candidate eigenvectors whose Moran's I value fulfilled the condition that $M I / \max (M I) \geq 0.25$ (see Griffith, 2003). The obtained eigenvectors are 39 and are denoted by $E_{1}, E_{2}, \ldots, E_{39}$.

3) Select, from the 39 candidate eigenvectors, the significant set of eigenvectors for each cross-section. This is performed separately for every year, using a stepwise logistic regression estimated with a GLM with identity link function. The regression stage is based on Akaike Information Criterion (AIC) and as this criterion tends to the overselection, a manual backwards removal of regressors (eigenvectors) is performed.

4) Determine the eigenvectors found in step 3) common to all the years.

5) Estimate the panel model whose independent variables are the explanatory variables and the eigenvectors obtained in step 4) that here are proxies for spatially distributed region-specific information (e.g., the endowment of natural resources, or the size of the 'home market') that is usually incorporated in the fixed effects parameters.

The panel model with spatially structured random effects, in addition, is able to capture dependence obtained throughout space in the whole period. To reach this aim a Mixed Generalized Linear Model with an intercept that varies spatially according to a normal distribution is used. The advantage of using this kind of model relies in the exact identification of the time specific effects via spatial eigenvectors, which are able also to take into account the spatial dimension of the omitted variables. Then, we will avoid the degree of freedom problems, typical of fixed effect framework and we will account explicitly for the spatial dimension of time invariant variables, without the need to surrogate this dimension with the use of specific dummies.

In the context of our analysis, we think that we do not face an endogeneity problem. This is well explained by Russel (1985: 42) who made clear that "the Italian 'railway boom' was not the driving stimulus to industrial development that it was elsewhere" and he adds that "the process of railway building was not closely related to the progress of industry in time or space". 


\section{Results}

The estimated baseline model is in table 3 . The coefficient of railways is positive and highly significant across all specifications. The result is in line with Aschauer's (1989) idea that differences in the stocks of public infrastructure and private capital could provide an important explanation for differences in levels of output. Other things being equal, railways increase productivity throughout the country, with no significant differences between the North and the South. In additional regressions we find that the South dummy is not significantly different from zero, therefore excluding the presence of a dichotomy per se due to a pure geographical criterion.

Also the dummy indicating the provinces characterized by the higher initial endowment of railways is not significant, showing that they did not get a permanent advantage from the early construction of this transport infrastructure. This is due to the type of industrial production, which was much related to the exploitation of natural (mainly water) resources and then located near them. Water was the fundamental in the textile industry (Federico, 2005) and the main resource used in electricity production (Bezza, 1986). Water was unevenly distributed across Italy, with the North enjoying an abundant and stable supply, not available in the South. Railways, then, served as a link between firms - which located close to water and electricity plants - and the main markets. The early presence of this infrastructure reduced travel time making it possible to increase the reachable potential market, but it did not produce a comparative and lasting advantage by itself. An explanation of the absence of permanent advantage for those regions with an early presence of railways can be found in the lack of complementary infrastructure, mainly roads whose situation was particularly bad, or in the underutilization of the railways for the lack of connections, that did not generate an appreciable advantage in the territories where this infrastructure came first.

However, the lack of difference between the North and the South stops here. The interaction term between the mentioned dummy and the constructed $\mathrm{km}$ of railways allows us to check whether the clusters of provinces that benefitted first from this infrastructure had a comparative advantage from the enlargement of the network. Results in models (5) and (6) show that this variable is positive and significant: the addition of a new railway in early infrastructured provinces leads to an additional advantage in productivity of these provinces, contributing to the divergent spatial patterns clearly shown in figure 5 and table 2 . To this extent, it is interesting to observe that, of the 13 provinces belonging to first quadrant (highhigh) of the Moran Scatterplot (figure 6), 11 belong also to the group with early railways construction. From this result we can state that under equal conditions with respect to natural 
resources, provinces with early railways are more productive because they exploit the whole potential of new railways construction that have a direct multiplier effect within each provinces. On the other hand, we have that the presence of a widespread network tends to concentrate its positive effects in a strict number of provinces without spreading its potential positive effects to the neighbors.

Was there enough trade between the North and the South to motivate this developments? Zamagni (1983) and Fenoaltea (1983) claimed that there was little scope for trade between northern and southern Italy because of the little complementarity between the goods produced. However, as Schram (1998) documented, imports by rail from southern Italy grew from 67,340 tons in 1867 (a mere 9\% of overall import) to 107,536 tons in 1870, 225,468 tons in $1875,327,886$ tons in 1880 and 346,423 tons in 1884 (12\% of the total). At the same time, export by rail to southern Italy was 121,013 tons in 1867 (34\% of the total), 89,927 tons in $1870,144,149$ tons in $1875,175,550$ tons in 1880 and 202,258 tons in 1884 (24\% of overall exports). Economic integration between the two areas strongly increased in absolute terms, with the North importing more than the South, but concentrating in raw and intermediate materials that were further processed in northern factories. Therefore the value adding process mostly took place in this area. ${ }^{10}$ Moreover, 60 percent of the traffic was on the northern network, and also within this area we observe some sluggishness in the distribution of productivity over time (figure $4 \mathrm{i}$ and 41 ). Finally, even if trade by rail concerned more neighboring countries than the South, this would enhance the productivity of the North with respect to those of the South, increasing the gap between the two areas.

We also find some positive and negative interactions between railways and other transportation means. First, we find that national and provincial roads, on the one hand, and municipal roads, on the other hand, although less significant, are positive. Second, the interaction term between railways and municipal roads is positive but little significant, claiming that it is possible that these two types of infrastructure tend to reciprocally strengthen their effect on productivity. Conversely, the interaction term of railways with national/provincial roads is negative. For the interpretation of the partial effect we refer to

\footnotetext{
${ }^{10}$ Openness to trade should not be very high in order to call an area integrated. Consider the US: in 2013 exports were $13.5 \%$ of GDP (World Bank Economic Indicators), yet it is extremely integrated in world trade, with the Silicon Valley setting the pace of technological innovation to the rest of the world, and low-skilled workers suffering from cheap imports from China (Freeman, 1995). The European Union is another example (De Grauwe, 2014): in 2007 large countries such as Germany, France and Italy exported to other EU members $25.9 \%, 14.0 \%$ and $13.9 \%$ of their overall exports, respectively. Smaller countries have much higher percentages, but all of them are largely integrated in the European single market (and many of them in the European Monetary Union).
} 
model (6), which is best model in terms of AIC. Model (6), then, is the one that best fits the results highlighting that the variables that have the most important role in explaining productivity are provincial/national and municipal roads, railways, the relevant interaction terms and the interaction term between railways and the dummy concerning their early construction.

In model (6) the partial derivative of Gross Value Added per male person with respect to municipal roads is:

$$
\frac{\partial \log (G V A / M P O P)}{\partial \log (1+R A I L)}=11.657-30.212 \log \left(1+N A T_{-} R O A D S\right)
$$

If we want to know what is the level of communal roads that make positive the impact of railways we have to make the previous equation equal to zero:

$$
\begin{aligned}
& 11.657-30.212 \log \left(1+N A T_{-} R O A D S\right) \geq 0 \Leftrightarrow 0.385 \geq \log \left(1+N A T_{-} R O A D S\right) \\
& \Leftrightarrow \exp (0.385) \geq 1+N A T_{-} R O A D S \Leftrightarrow 0.470 \geq N A T_{-} \text {ROADS }
\end{aligned}
$$

The density of national and provincial roads needs to be less than $0.47 \mathrm{~km}$ per squared $\mathrm{km}$ in order to have a positive impact on railways. Until 1901 the maximum $\mathrm{km}$ of roads per squared $\mathrm{km}$ was less than 0.47 , and only in 1911 we have a province above this threshold. The explanation is probably in the substitution effect recalled by Zingaretti (1929). The national roads have the advantage to be cheaper because it was not required the payment of a ticket to access, but they were slower. A higher density of these roads, then, lowers the use of railways and then their positive impact on productivity.

In some contrast with the previous results on roads, the distance from the nearest port of primary importance is negative as expected, but the statistically significance is very limited. The explanation can be related to the phases of Italian industrialization: initially, around 1870, production was essentially devoted to local consumption, and then the ports were not of great importance for trading goods; subsequently the problem of distance between markets and from ports has been overcome by the improvement of transport infrastructure, mainly railways. Furthermore, Fenoaltea (1983) showed that Genoa was the main port for Northern industrialization, connecting it with Turin via railway, but its physical limits constrained its development. Agglomeration is significant and positive, which is related with the importance of the domestic market as well as the presence of a larger labor market. 
Finally, in each regression we have different sets of selected eigenvectors. This is due to the combination of variables selected for each model, and their capacity to fit the data, that implies a different combination of additional regressors (the eigenvectors) that surrogate the missing explanatory independent variables. Ideally, the eigenvectors can be associated with a geographical scale. Thus, a first set is related to a large Moran's I, i.e. the eigenvectors represent large clusters of provinces, a second set has medium scale and a third a local scale. From the selected eigenvectors, we have some information regarding the spatial pattern of the omitted variables not explicitly considered in the regression. In our case we have differentiated eigenvectors for each estimate and we do not have a clear prevalence of a determined set of eigenvectors. This indicates that the explanatory variables do not accounted in the analysis do not have a clear geographical scale. The (unconsidered) factors that affect productivity, then, do not have an explicit relation to the geography but have a stronger relation with the endogenous provincial characteristics. This is made clear from the figure in Appendix 2 where we plot the eigenvectors of Model (6) taken as reference.

\section{Robustness checks}

This section assesses the robustness of the results for the effect of public capital presented above. We check the sensitivity of the estimates to alternative definitions of the spatial weights matrix. Our analysis, so far, considered as a contiguity criterion a mix of geographical distance and economic characteristics. The possibility other types of proximities is investigated in order to check whether the results obtained are conditional to the use of the contiguity.

The first alternative definition is purely aspatial and is based on the idea that the more similar the economies of two regions are, the greater their weights. Hence, following Moreno and Lopez-Bazo (2007) we will use population density as a rough proxy for agglomeration economies. To exhibit similarity in population density, the weights of the $\mathbf{W}$ matrix are constructed as follows:

$$
w_{i j}=\frac{1}{\left|P O P_{-} D E N S_{i}-P O P_{-} D E N S_{j}\right|}
$$

The resulting weights matrix accounts only for similarity in population density between each pair of regions, irrespective of their proximity. According to the mentioned authors the idea behind this specification is that much more similar are two regions, more 
they compete for mobile factors of production. Thus, this matrix is a proxy for how economies compete.

The results in table 4 show that the signs and significance of the parameters is very close to previous estimation. The main difference is that the parameter associated to the distance from the main ports is not significant in any model. The second specification of matrix $\mathbf{W}$ is based on geographical criterion. We define two regions as neighbor if they share their respective boundaries for at least a point. In this case we consider the interrelation only caused by geographical proximity. Table 5 confirms our previous results in terms of significant variables and signs. 
Table 3: panel data estimation (mkt potential matrix)

\begin{tabular}{|c|c|c|c|c|c|c|c|c|c|c|}
\hline & (1) & (2) & (3) & (4) & (5) & & (6) & & (7) & (8) \\
\hline Intercept & $\begin{array}{l}4.840 \text { *** } \\
(0.114)\end{array}$ & $\begin{array}{l}4.725 * * * \\
(0.127)\end{array}$ & $\begin{array}{l}4.672 \text { *** } \\
(0.116)\end{array}$ & $\begin{array}{l}4.569 \text { *** } \\
(0.128)\end{array}$ & $\begin{array}{r}4.396 \\
(0.068)\end{array}$ & $* * *$ & $\begin{array}{r}3.433 \\
(0.284)\end{array}$ & $* * *$ & $\begin{array}{l}3.492 \text { *** } \\
(0.316)\end{array}$ & $\begin{array}{l}4.606 \text { *** } \\
(0.131)\end{array}$ \\
\hline Railways & $\begin{array}{l}7.920 * * * \\
(0.692)\end{array}$ & $\begin{array}{l}8.287 \text { *** } \\
(0.707)\end{array}$ & $\begin{array}{l}13.010 * * * \\
(1.058)\end{array}$ & $\begin{array}{l}12.845 \text { *** } \\
(1.07)\end{array}$ & $\begin{array}{r}12.470 \\
(1.071)\end{array}$ & $* * *$ & $\begin{array}{l}11.657 \\
(1.072)\end{array}$ & $* * *$ & $\begin{array}{l}11.787 * * * \\
(1.096)\end{array}$ & $\begin{array}{l}12.541 * * * \\
(1.073)\end{array}$ \\
\hline $\begin{array}{l}\text { National/provincial } \\
\text { roads }\end{array}$ & $\begin{array}{l}0.755 * * \\
(0.237)\end{array}$ & $\begin{array}{l}0.671 * * \\
(0.236)\end{array}$ & $\begin{array}{l}2.834 * * * \\
(0.418)\end{array}$ & $\begin{array}{l}2.802 \text { *** } \\
(0.427)\end{array}$ & $\begin{array}{r}2.459 \\
(0.425)\end{array}$ & *** & $\begin{array}{r}2.531 \\
(0.405)\end{array}$ & $* * *$ & $\begin{array}{l}2.582 * * * \\
(0.416)\end{array}$ & $\begin{array}{l}2.682 \text { *** } \\
(0.425)\end{array}$ \\
\hline Municipal roads & $\begin{array}{l}0.653 * * * \\
(0.135)\end{array}$ & $\begin{array}{l}0.724 * * * \\
(0.133)\end{array}$ & $\begin{array}{l}0.447 * * \\
(0.21)\end{array}$ & $\begin{array}{l}0.413 * \\
(0.217)\end{array}$ & $\begin{array}{r}0.500 \\
0.214)\end{array}$ & $* *$ & $\begin{array}{r}0.425 \\
(0.406)\end{array}$ & & $\begin{array}{r}0.359 \\
(0.220)\end{array}$ & $\begin{array}{r}0.367 \\
(0.224)\end{array}$ \\
\hline Distance from ports & $\begin{array}{r}-0.039 \\
(0.023)\end{array}$ & $\begin{array}{r}-0.021 \\
(0.025)\end{array}$ & $\begin{array}{l}-0.068 * * \\
(0.023)\end{array}$ & $\begin{array}{l}-0.046 * \\
(0.025)\end{array}$ & & & & & & $\begin{array}{l}-0.041 \\
(0025)\end{array}$ \\
\hline Dummy Moran & & $\begin{array}{r}0.072 \\
(0.088)\end{array}$ & & $\begin{array}{r}0.098 \\
(0.084)\end{array}$ & & & & & & \\
\hline Dummy South & & & & & & & & & $\begin{array}{r}-0.081 \\
(0.088)\end{array}$ & $\begin{array}{r}-0.017 \\
(0.089)\end{array}$ \\
\hline Agglomeration & & & & & & & $\begin{array}{r}0.212 \\
(0.063)\end{array}$ & $* * *$ & $\begin{array}{l}0.214 \text { *** } \\
(0.069)\end{array}$ & \\
\hline $\begin{array}{l}\text { National/provincial } \\
\text { roads } \times \text { Railways }\end{array}$ & & & $\begin{array}{l}-34.117^{* * *} \\
(5.514)\end{array}$ & $\begin{array}{l}-33.386 \\
(5.629)\end{array}$ & $\begin{array}{r}-28.823 \\
(5.624)\end{array}$ & $* * *$ & $\begin{array}{r}-30.212 \\
(5.363)\end{array}$ & $* * *$ & $\begin{array}{l}-30.7366^{* * *} \\
(5.497)\end{array}$ & $\begin{array}{l}-30.919 \text { *** } \\
(5.650)\end{array}$ \\
\hline $\begin{array}{l}\text { Municipal } \\
\text { roads } \times \text { Railways }\end{array}$ & & & ${ }^{5.829}{ }^{* *}$ & $\begin{array}{r}5.851 \\
(2.815)\end{array}$ & $\begin{array}{r}3.765 \\
(2.814)\end{array}$ & & $\begin{array}{r}4.203 \\
(2.694)\end{array}$ & & $\begin{array}{r}5.443 \\
(2.742)\end{array}$ & $\begin{array}{r}5.199 \\
(2.842)\end{array}$ \\
\hline $\begin{array}{l}\text { Dummy Moran } \\
\times \text { Railways }\end{array}$ & & & & & $\begin{array}{r}2.561 \\
(1.226)\end{array}$ & $* * *$ & $\begin{array}{r}3.642 \\
(1.197)\end{array}$ & $* * *$ & & \\
\hline $\begin{array}{l}\text { Common } \\
\text { eigenv. }\end{array}$ & $\begin{array}{c}\text { E1, E12, } \\
\text { E17, E22, } \\
32, \text { E37 }\end{array}$ & $\begin{array}{c}\text { E2, E12, } \\
\text { E21, E32, } \\
\text { E33, E36 }\end{array}$ & $\begin{array}{l}\text { E8, E12, } \\
\text { E17, E21, } \\
\text { E22, E36 }\end{array}$ & $\begin{array}{l}\text { E6, E12, } \\
\text { E22, E32, } \\
\text { E36 }\end{array}$ & E32 & & $\begin{array}{l}\text { E12, E22 } \\
\text { E34, E3 }\end{array}$ & & $\begin{array}{l}\text { E7, E12, } \\
\quad \text { E32 }\end{array}$ & $\begin{array}{l}\text { E1, E12, } \\
\quad \text { E17 }\end{array}$ \\
\hline $\mathrm{AIC}$ & 121.411 & 135.692 & 78.731 & 89.968 & 78.617 & & 61.936 & & 90.221 & 94.774 \\
\hline
\end{tabular}

*Significant at $1 \%, * *$ significant at $5 \%, * * *$ significant at $10 \%$. 
Table 4: panel data estimation (dens)

\begin{tabular}{|c|c|c|c|c|c|c|c|c|c|c|}
\hline & (1) & (2) & (3) & (4) & $(5$ & & $(6$ & ) & (7) & (8) \\
\hline Intercept & $\begin{array}{l}4.732 * * * \\
(0.114)\end{array}$ & $\begin{array}{l}4.714 * * * \\
(0.124)\end{array}$ & $\begin{array}{l}4.56 \text { *** } \\
(0.123)\end{array}$ & $\begin{array}{l}4.524 * * * \\
(0.126)\end{array}$ & $\begin{array}{r}4.400 \\
(0.068)\end{array}$ & $* * *$ & $\begin{array}{r}3.483 \\
(0.298)\end{array}$ & $* * *$ & $\begin{array}{l}3.575 * * * \\
(0.316)\end{array}$ & $\begin{array}{l}4.604 * * * \\
(0.132)\end{array}$ \\
\hline Railways & $\begin{array}{l}8.149 \text { *** } \\
(0.692)\end{array}$ & $\begin{array}{l}8.082 \text { *** } \\
(0.700)\end{array}$ & $\begin{array}{l}12.665 * * * \\
(1.061)\end{array}$ & $\begin{array}{l}12.752 \text { *** } \\
(1.068)\end{array}$ & $\begin{array}{r}12.445 \\
(1.076)\end{array}$ & $* * *$ & $\begin{array}{l}11.648 \\
(1.080)\end{array}$ & $* * *$ & $\begin{array}{l}11.804 * * * \\
(1.106)\end{array}$ & $\begin{array}{l}12.590 * * * \\
(1.069)\end{array}$ \\
\hline $\begin{array}{l}\text { National/provincial } \\
\text { roads }\end{array}$ & $\begin{array}{l}0.58 * * \\
(0.233)\end{array}$ & $\begin{array}{l}0.612 \text { ** } \\
(0.235)\end{array}$ & $\begin{array}{l}2.596 * * * \\
(0.42)\end{array}$ & $\begin{array}{l}2.655 \text { *** } \\
(0.422)\end{array}$ & $\begin{array}{r}2.518 \\
(0.443)\end{array}$ & $* * *$ & $\begin{array}{r}2.416 \\
(0.409)\end{array}$ & $* * *$ & $\begin{array}{l}2.518 \text { *** } \\
(0.434)\end{array}$ & $\begin{array}{l}2.680 * * * \\
(0.423)\end{array}$ \\
\hline Municipal roads & $\begin{array}{l}0.799 * * * \\
(0.128)\end{array}$ & $\begin{array}{l}0.733 * * * \\
(0.132)\end{array}$ & $\begin{array}{l}0.481 \text { ** } \\
(0.214)\end{array}$ & $\begin{array}{l}0.479 * * \\
(0.214)\end{array}$ & $\begin{array}{r}0.483 \\
(0.215)\end{array}$ & $* *$ & $\begin{array}{r}0.487 \\
(0.208)\end{array}$ & $* *$ & $\begin{array}{r}0.355 \\
(0.218)\end{array}$ & $\begin{array}{r}0.360 \\
(0.224)\end{array}$ \\
\hline Distance from ports & $\begin{array}{r}-0.018 \\
(0.023)\end{array}$ & $\begin{array}{r}-0.015 \\
(0.024)\end{array}$ & $\begin{array}{r}-0.034 \\
(0.024)\end{array}$ & $\begin{array}{l}-0.032 \\
(0.024)\end{array}$ & & & & & & $\begin{array}{r}-0.034 \\
(0.025)\end{array}$ \\
\hline Dummy Moran & & $\begin{array}{r}0.081 \\
(0.085)\end{array}$ & & $\begin{array}{r}0.068 \\
(0.086)\end{array}$ & & & & & & \\
\hline Dummy South & & & & & & & & & $\begin{array}{r}-0.084 \\
(0.856)\end{array}$ & $\begin{array}{r}-0.090 \\
(0.080)\end{array}$ \\
\hline Agglomeration & & & & & & & $\begin{array}{r}0.204 \\
(0.066)\end{array}$ & $* * *$ & $\begin{array}{l}0.198 * * * \\
(0.070)\end{array}$ & \\
\hline National/provincial & & & $* * *$ & $* * *$ & -30.008 & $* *$ & -29.801 & $* * *$ & $* * *$ & $-* * *$ \\
\hline roads $\times$ Railways & & & $\begin{array}{r}-31.154 \\
(5.575)\end{array}$ & $\begin{array}{r}-31.887 \\
(5.609)\end{array}$ & $(6.072)$ & & $(5.413)$ & & $\begin{array}{r}-29.474 \\
(5.931)\end{array}$ & $\begin{array}{r}31.586 \\
(5.685)\end{array}$ \\
\hline $\begin{array}{l}\text { Monicipal } \\
\text { roads } \times \text { Railways }\end{array}$ & & & $\begin{array}{r}4.877 \\
(2.792)\end{array}$ & $\begin{array}{r}5.099 \\
(2.791)\end{array}$ & $\begin{array}{r}4.175 \\
(2.890)\end{array}$ & & $\begin{array}{r}3.735 \\
(2.708)\end{array}$ & & $\begin{array}{r}4.993 \\
(2.805)\end{array}$ & $\begin{array}{l}5.685^{* *} \\
(2.820)\end{array}$ \\
\hline $\begin{array}{l}\text { Dummy Moran } \\
\times \text { Railways }\end{array}$ & & & & & $\begin{array}{r}2.378 \\
(1.221)\end{array}$ & $*$ & $\begin{array}{r}2.693 \\
(1.213)\end{array}$ & $* *$ & & \\
\hline $\begin{array}{l}\text { Common } \\
\text { eigenv. }\end{array}$ & E8, E17 & $\begin{array}{l}\text { E17, E23, } \\
\quad \text { E35 }\end{array}$ & $\begin{array}{l}\text { E8, E17, } \\
\quad \text { E23 }\end{array}$ & $\mathrm{E} 17, \mathrm{E} 22$ & $\begin{array}{r}\text { E1, } \\
\text { E8, E1 }\end{array}$ & $\begin{array}{l}\text { E7, } \\
7, \text { E28 }\end{array}$ & $\begin{array}{r}\text { E6, } \\
\text { E17, }\end{array}$ & $\begin{array}{l}\text { E8 } \\
\text { E22 }\end{array}$ & $\begin{array}{l}\text { E17, E23, } \\
\quad \text { E28 }\end{array}$ & E7, E17 \\
\hline AIC & 127.641 & 114.767 & 84.308 & 86.630 & 82.4 & 23 & 68.6 & 653 & 83.719 & 92.071 \\
\hline
\end{tabular}

*Significant at $1 \%$, ** significant at 5\%,*** significant at $10 \%$. 
Table 5: panel data estimation (queen)

\begin{tabular}{|c|c|c|c|c|c|c|c|c|c|c|}
\hline & (1) & (2) & (3) & (4) & $(5$ & & $(6$ & & (7) & (8) \\
\hline Intercept & $\begin{array}{l}4.709 \text { *** } \\
(0.445)\end{array}$ & $\begin{array}{l}4.695 \text { *** } \\
(0.125)\end{array}$ & $\begin{array}{l}4.542 \text { *** } \\
(0.126)\end{array}$ & $\begin{array}{l}4.546 * * * \\
(0.13)\end{array}$ & $\begin{array}{r}4.402 \\
(0.067)\end{array}$ & $* * *$ & $\begin{array}{r}3.420 \\
(0.306)\end{array}$ & $* * *$ & $\begin{array}{l}3.704 * * * \\
(0.282)\end{array}$ & $\begin{array}{l}4.592 * * * \\
(0.131)\end{array}$ \\
\hline Railways & $\begin{array}{l}8.152 \text { *** } \\
(1.445)\end{array}$ & $\begin{array}{l}8.12 \text { *** } \\
(0.701)\end{array}$ & $\begin{array}{l}12.683 * * * \\
(1.063)\end{array}$ & $\begin{array}{l}12.687 * * * \\
(1.071)\end{array}$ & $\begin{array}{r}12.393 \\
(1.071)\end{array}$ & $* * *$ & $\begin{array}{r}11.550 \\
(1.087)\end{array}$ & $* * *$ & $\begin{array}{l}11.876 * * * \\
(1.085)\end{array}$ & $\begin{array}{l}12.569 * * * \\
(1.067)\end{array}$ \\
\hline $\begin{array}{l}\text { National/provincial } \\
\text { roads }\end{array}$ & $\begin{array}{l}0.644 * * \\
(2.445)\end{array}$ & $\begin{array}{l}0.653 * * \\
(0.235)\end{array}$ & $\begin{array}{l}2.62 * * \\
(0.422)\end{array}$ & $\begin{array}{l}2.630 * * * \\
(0.426)\end{array}$ & $\begin{array}{r}2.441 \\
(0.423)\end{array}$ & $* * *$ & $\begin{array}{r}2.475 \\
(0.412)\end{array}$ & $* * *$ & $\begin{array}{l}2.632 \text { *** } \\
(0.408)\end{array}$ & $\begin{array}{l}2.629 * * * \\
(0.422)\end{array}$ \\
\hline Municipal roads & $\begin{array}{l}0.747 * * * \\
(3.445)\end{array}$ & $\begin{array}{l}0.727 * * * \\
(0.132)\end{array}$ & $\begin{array}{l}0.462 * * * \\
(0.214)\end{array}$ & $\begin{array}{l}0.457 * * \\
(0.215)\end{array}$ & $\begin{array}{r}0.501 \\
(0.213)\end{array}$ & $* *$ & $\begin{array}{r}0.417 \\
(0.208)\end{array}$ & $* *$ & $\begin{array}{r}0.330 \\
(0.217)\end{array}$ & $\begin{array}{l}0.386 * \\
(0.223)\end{array}$ \\
\hline Distance from ports & $\begin{array}{r}-0.012 \\
(4.445)\end{array}$ & $\begin{array}{r}-0.012 \\
(0.025)\end{array}$ & $\begin{array}{r}-0.031 \\
(0.025)\end{array}$ & $\begin{array}{l}-0.033 \\
(0.025)\end{array}$ & & & & & & $\begin{array}{r}-0.311 \\
(0.025)\end{array}$ \\
\hline Dummy Moran & & $\begin{array}{r}0.086 \\
(0.086)\end{array}$ & & $\begin{array}{r}0.024 \\
(0.088)\end{array}$ & & & & & & \\
\hline Dummy South & & & & & & & & & $\begin{array}{r}-0.075 \\
(0.077)\end{array}$ & $\begin{array}{r}-0098 \\
(0.079)\end{array}$ \\
\hline Agglomeration & & & & & & & $\begin{array}{r}0.219 \\
(0.068)\end{array}$ & $* * *$ & $\begin{array}{l}0.167 * * * \\
(0.062)\end{array}$ & \\
\hline $\begin{array}{l}\text { National/provincial } \\
\text { roads } \times \text { Railways }\end{array}$ & & & $\begin{array}{l}-31.088 * * * \\
(5.615)\end{array}$ & $\begin{array}{l}-31.100 * * * \\
(5.67)\end{array}$ & $\begin{array}{l}-28.374 \\
(5.608)\end{array}$ & $* * *$ & $\begin{array}{l}-29.379 \\
(5.512)\end{array}$ & $* * *$ & $\begin{array}{l}-31.231 * * * \\
(5.398)\end{array}$ & $\begin{array}{l}-30.681 * * * \\
(5.620)\end{array}$ \\
\hline $\begin{array}{l}\text { Monicipal } \\
\text { roads } \times \text { Railways }\end{array}$ & & & $\begin{array}{l}5.048 * \\
(2.799)\end{array}$ & $\begin{array}{l}5.061 * \\
(2.808)\end{array}$ & $\begin{array}{r}3.737 \\
(2.809)\end{array}$ & & $\begin{array}{r}4.357 \\
(2.742)\end{array}$ & & $\begin{array}{l}5.734 * * \\
(2.711)\end{array}$ & $\begin{array}{l}5.313 * \\
(2.809)\end{array}$ \\
\hline $\begin{array}{l}\text { Dummy Moran } \\
\times \text { Railways }\end{array}$ & & & & & $\begin{array}{r}2.335 \\
(1.211)\end{array}$ & $*$ & $\begin{array}{r}2.386 \\
(1.241)\end{array}$ & $*$ & & \\
\hline $\begin{array}{l}\text { Common } \\
\text { eigenv. }\end{array}$ & E33, E42 & E33 & $\mathrm{E} 33, \mathrm{E} 42$ & E33 & E33, & $\mathrm{E} 42$ & $\begin{array}{l}\text { E18 } \\
\text { E33, }\end{array}$ & $\begin{array}{l}32, \\
\mathrm{E} 45\end{array}$ & $\begin{array}{l}\text { E9, E33, } \\
\text { E42, E45, } \\
\text { E49 }\end{array}$ & E33, E42 \\
\hline AIC & 123.095 & 127.192 & 86.610 & 91.380 & 76. & 98 & 76. & 599 & 76.988 & 90.329 \\
\hline
\end{tabular}

*Significant at 1\%,** significant at 5\%,*** significant at $10 \%$. 


\section{Conclusions}

This paper provided the first evidence based on spatial econometrics on the effects of railway construction in post-Unification Italy. We find evidence consistent with the NEG which claims that the development of transport infrastructure, by increasing the accessibility of weaker regions, "not only gives firms in less developed regions better access to inputs and markets of more developed regions [. . .] but it also makes it easier for firms in richer regions to supply poorer regions at a distance, and can thus harm the industrialization prospects of less developed areas" (Puga 2002: 396). Our results add some empirical evidence to what found by Martin and Rogers (1995) and Martin (1998), highlighting that public infrastructure facilitates transactions inside the cluster of regions that built railways at the expenses of provinces that did not experience this early infrastructure endowment.

The situation in Italy after the unification was not so strongly polarized in terms of productivity, but it was in terms of infrastructure and natural resources endowments. The effort of the Kingdom to provide a balanced infrastructure level produced some results that did not translate into a unbiased productivity evolution over the 40 considered years. The combined advantage of water availability and of early construction of railways made that some provinces developed more than others did but without benefiting to the surrounding provinces. Therefore, the initial gap in industrial productivity persisted and mostly increased over time.

Interestingly, the identification of the North-West - the first comer in railway construction - as the main beneficiary of this endeavor is similar to Fenoaltea $(1983,2011)$ although our results are less pessimistic on the overall evaluation of the effects of railways, which brought an increase in industrial productivity across the board. 


\section{References}

Aschauer D.A. (1989). Is public expenditure productive?. Journal of Monetary Economics, 23: $177-200$.

Andersson M., Karlsson C. (2007). Knowledge in Regional Economic Growth - The Role of Knowledge Accessibility. Industry and Innovation, 14: 129-149.

Annuario Statistico Italiano (1892, 1900, 1912). Roma.

Badon C. (2011). Le vie dell'Italia unita. La politica stradale italiana nell'epoca delle ferrovie (1850-1900). Nerbini, Firenze.

Barro R., (1990). Government Spending in a Simple Model of Endogenous Growth, Journal of Political Economy, 98: 103-125.

Bogart D. (2010). A global perspective on railway inefficiency and the rise of state ownership, 1880-1912, Explorations in Economic History 47: 158-178.

Bezza B. (1986). Energia e sviluppo. L'industria elettrica italiana e la Società Edison. Einaudi, Torino

Cavour C. (1976). Le strade ferrate in Italia, a cura di A. Salvestrini, La Nuova Italia, Firenze.

Ciccarelli C., Fenoaltea S. (2012). The Rail-Guided Vehicles Industry in Italy, 1861-1913: The Burden of the Evidence, in C. Hanes, S. Wolcott (ed.) Research in Economic History, Volume 28, Emerald Group Publishing Limited, pp.43-115.

Ciccarelli C., Fenoaltea S. (2013). Through the magnifying glass: provincial aspects of industrial growth in post-Unification Italy. Economic History Review, 66, 57-85.

Ciccarelli C., Nuvolari A. (2015). Technical change, non-tariff barriers, and the development of the Italian locomotive industry, 1850-1913, Journal of Economic History, forthcoming.

Daniele V. and Malanima, P., (2007). Il prodotto delle regioni e il divario Nord-Sud in Italia (1861-2004), Rivista di politica economica, 97, 267-315.

Del Bo C., Florio M. (2012). Infrastructure and Growth in a Spatial Framework: Evidence from the EU regions. European Planning Studies, 20: 1393-1414.

De Grauwe P. (2014). Economics of Monetary Union, Oxford University Press.

Dincecco M., Federico G., Vindigni A. (2011). Warfare, taxation and political change: evidence from the Italian Risorgimento, Journal of Economic History, 71, 887-914.

ESPON (2007). Update of selected potential accessibility indicators (Final report).

Dortmund, Spiekermann \& Wegener: 
http://www.espon.eu/export/sites/default/Documents/Projects/ESPON2006Projects/Sci entificBriefingNetworking/UpdateOnAccessibilityMaps/espon_accessibility_update_20 06_fr_070207.pdf (accessed 07 April 2015).

Federico G. (2005). Seta, agricoltura e sviluppo economico in Italia, Rivista di Storia Economica, 21, 117-149.

Felice, E. (2011). Regional value added in Italy, 1891-2001, and the foundation of a longterm picture, Economic History Review, 64, 929-950.

Fenoaltea, S. (2003). Peeking backward: regional aspects of industrial growth in postUnification Italy, Journal of Economic History, 63, 1059-102.

Fenoaltea S. (1983). Italy. In P. O’Brien (ed.), Railways and the Economic Development of Europe. Oxford: Macmillan.

Fenoaltea S. (2007). I due fallimenti della storia economica: il periodo post-unitario. Rivista di Politica Economica. Marzo-Aprile 2007, 341-358.

Fenoaltea S. (2011). The Reinterpretation of Italian Economic History, Cambridge MA.

Ferrovie dell'Alta Italia, Esercizio, Servizio della contabilità e del controllo, Statistica anno 1865, Civelli, Milano s.d.

Freeman R.B. (1995). Are Your Wages Set in Beijing?, Journal of Economic Perspectives, 9, $15-32$.

Giornale del Genio civile (1869), parte ufficiale.

Gerschenkron A. (1962). Economic backwardness in historical perspective, Cambridge, Massachusetts: Belknap Press of Harvard University Press.

Getis A., Griffith D.A., (2002). Comparative Spatial Filtering in Regression Analysis, Geographical Analysis, 34: 130-140.

Griffith D.A. (2003). Spatial autocorrelation and spatial filtering: gaining understanding through theory and scientific visualization, Springer, Berlin.

Krugman P. (1991). Increasing Returns and Economic Geography. Journal of Political Economy, 99: 483-499.

Krugman P., Venables A. (1995). Globalization and the Inequality of Nations, Quarterly Journal of Economics, 110: 857-880.

Holtz-Eakin D., Schwartz A.E., (1995). Infrastructure in a structural model of economic growth Regional Science and Urban Economics, 25: 131-151.

L'Italia Economica (1873). Roma

L'XI legislatura: memorie di un defunto / per l'avvocato Angelo Mazzoleni Milano: Manini, 1875. 
Lewis B.D. (1998). The impact of public infrastructure on municipal economic development: Empirical results from Kenya. Review of Urban and Regional Development Studies 10: 142-155.

Martin P., (1998). Can Regional Policies Affect Growth and Geography in Europe?, The World Economy, 21: 757-774.

Martin P., Rogers A.R. (1995). Industrial Location and Public Infrastructure, Journal of International Economics, 39: 335-351.

Merger M. (1986). Un modello di sostituzione: la locomotiva italiana dal 1850 al 1914 , Rivista di storia economica, 3, 66-108

Ministero delle comunicazioni, Ferrovie dello Stato (1927). Sviluppo delle ferrovie italiane dal 1839 al 31 dicembre 1926.

Moreno R., López-Bazo E. (2007). Returns to Local and Transport Infrastructure under Regional Spillovers. International Regional Science Review, 30, 1: 47-71.

Patuelli R., Griffith D., Tiefelsdorf M., Nijkamp P. (2011). Spatial filtering and eigenvector stability: space-time models for German unemployment data, International Regional Science Review, 34: 253-280.

Puga D. (2002). European regional policies in the light of recent location theories. Journal of Economic Geography 2: 373-406.

Rey S., (2001). Spatial Empirics for Economic Growth and Convergence, Geographical Analysis, 33: 195-214.

Rey S.J., Murray A.T., Anselin L. (2010). Visualising Regional Income Distribution Dynamics, GeoDa Spatial Center Working papers 14.

Romeo R. (1959). Risorgimento e capitalismo, Laterza, Bari.

Russel K. (1985). The Industrial Geography of Italy, Palgrave Macmillan.

Schram A. (1997). Railways and the Formation of the Italian State in the Nineteenth Century, Cambridge University Press.

Sereni E. (1966).Capitalismo e mercato nazionale in Italia, Roma, Editori riuniti.

Tiefelsdorf M., Boots B., (1995). The Exact Distribution of Moran's I, Environment and Planning A, 27: 985-999.

Wegener M., Eskelinnen H., Fürst F., Schürmann C., Spiekermann K. (2002). Criteria for the spatial differentiation of the EU territory: Geographical position. Forschungen 102.2, Bonn: Bundesamt für Bauwesen und Raumordnung.

Zamagni V. (1983). Ferrovie e integrazione del mercato nazionale nell'Italia post-unitaria, in Studi in onore di Gino Barbieri, Pisa, v.III. 
Zamagni V. (1993). The Economic History of Italy 1860-1990. Oxford: Clarendon Press.

Zingaretti F. (1929). Le vie ordinarie di comunicazione, Società Tipografica Leonardo da Vinci, Città di Castello. 
Appendix 1: covariance matrix

\begin{tabular}{lccccc}
\hline & Railways & $\begin{array}{c}\text { National/provincial } \\
\text { roads }\end{array}$ & Municipal roads & Distance from ports & Agglomeration \\
\hline Railways & 1.000 & 0.462 & 0.378 & -0.307 & 0.560 \\
National/provincial & 0.462 & 1.000 & 0.273 & -0.201 & 0.401 \\
roads & 0.378 & 0.273 & 1.000 & -0.079 & 0.401 \\
Municipal roads & -0.307 & -0.201 & -0.079 & 1.000 & -0.497 \\
Distance from ports & 0.560 & 0.401 & 0.401 & -0.497 & 1.000 \\
Agglomeration & & &
\end{tabular}

Appendix 2: selected eigenvectors of model (6), table 3

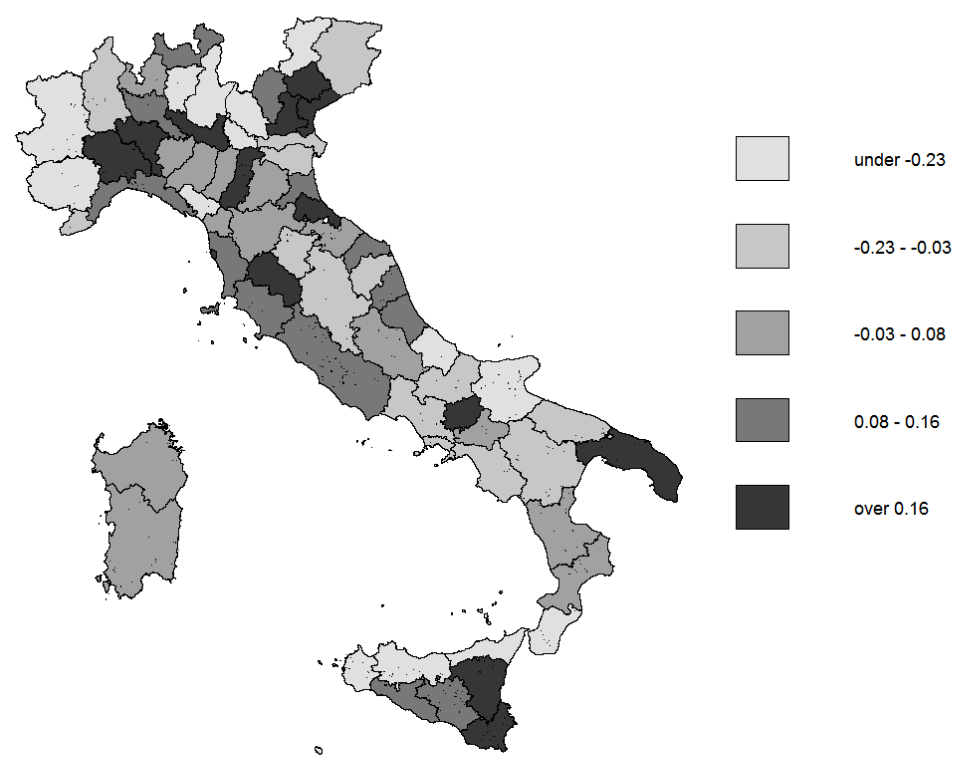

